\title{
El impacto del Brexit sobre el estatus jurídico-político de Irlanda del Norte: ¿una oportunidad para la reunificación de Irlanda?*
}

Eneko Compains Silva

DOI: https://doi.org/10.47623/ivap-rvap.109.2017.1.02

\begin{abstract}
Sumario: I. Introducción. II. El estatus jurídico-político de Irlanda del Norte: 1. El reconocimiento del derecho de autodeterminación como solución al conflicto político y armado. 2. La Northern Ireland Act: transferencia de competencias y mapa institucional.-III. El Brexit y sus implicaciones jurídico-constitucionales: 1. Los recursos contra el Brexit y la sentencia de la High Court de Belfast. 2. La Sentencia de la Corte Suprema del Reino Unido sobre el Brexit. 2.1. La cuestión principal: Gobierno Vs. Parlamento. Implicaciones del principio de soberanía parlamentaria. 2.2. La cuestión norirlandesa en relación al Brexit. 3. Síntesis: Irlanda del Norte no puede frenar el Brexit. 4. Un apunte desde el Derecho Internacional Público: ¿Qué posibilidades tiene la República de Irlanda de condicionar el Brexit?-IV. El Brexit y sus implicaciones a futuro: 1. La sociedad norirlandesa ante el Brexit. 2. Los partidos norirlandeses ante el Brexit. 3. Las posibilidades para un referéndum sobre la unidad de Irlanda. - V. Conclusiones. -VI. Bibliografía
\end{abstract}

\section{Introducción}

El día 6 de mayo de 2016, poco antes de celebrarse el referéndum de salida de la Unión Europea (en adelante UE), tuvo lugar en Dublín una interesante conferencia bajo el título "¿Una nueva relación? Brexit, República de Irlanda e Irlanda del Norte(1)». En la misma, al amparo de la Ro-

\footnotetext{
* El presente trabajo ha sido realizado al amparo del GIC 07/86 Derechos Fundamentales y Unión Europea, financiado por el Gobierno Vasco. Así mismo, su autor disfrutó de una beca de movilidad de investigadores otorgada por el Vicerrectorado de Investigación de la UPV, cuyo objetivo era facilitar la realización de una estancia de investigación en la Queen's University de Belfast entre los meses de junio y julio de 2017.
}

(1) "A new relationship? Brexit, Republic of Ireland and Northern Ireland", Royal Irish Academy (Dublin), 6 May 2016. 
yal Irish Academy y la Queen's University de Belfast, se analizaron distintos aspectos de un posible abandono de la UE por parte del Reino Unido que pudiese "arrastrar» fuera de la misma a Irlanda del Norte.

Con el fin de discutir sobre las alternativas de futuro, se fijó como hipótesis de debate algo que finalmente sucedió: que el Reino Unido globalmente apostase por el Brexit y que, sin embargo, algunas de las devolved regions votasen por mantenerse dentro de la UE (2) (Como es sabido, finalmente fueron Irlanda del Norte y Escocia quienes votaron remain, mientras Gales e Inglaterra votaron leave). En tal eventualidad, se afirmó, las opciones de futuro serían tres:

- La primera: que dichas regiones abandonasen de mala gana la UE, pero que la abandonasen, al fin y al cabo, arrastradas por Londres.

- La segunda: que dichas regiones decidieran negociar sus propias relaciones con la UE al margen de su gobierno nacional, algo que ya han hecho territorios como Gibraltar o las Channel Islands.

-Y la tercera: que se produjera la secesión de alguno de estos territorios con respecto al Reino Unido para poder así reintegrarse plenamente en la UE (3), de forma que ya no estaríamos sólo ante una reordenación de Europa sino ante una reconfiguración del propio Reino Unido (4).

¿Cuál de estas hipótesis parece más probable en Irlanda del Norte? ¿Qué efectos va a tener el Brexit allí? Responder estas y otras preguntas es precisamente el objeto de las siguientes páginas.

Para ello, se comenzará por explicar cuál es el estatus político de Irlanda del Norte hoy. Seguidamente se realizará un análisis jurídico-constitucional de las implicaciones del Brexit, haciendo especial hincapié en la transcendental sentencia de la Corte Suprema del Reino Unido sobre el tema (conocido como Caso Miller). En tercer lugar, se ofrecerá un somero análisis de las posiciones sociales y políticas que permita visualizar algunas alternativas de futuro. Y finalmente, se ofrecerán algunas consideraciones del autor a modo de conclusión. Sin más dilación, es hora de entrar en materia.

\footnotetext{
(2) En concreto, mientras que en el conjunto del Reino Unido el voto por el Brexit fue de un 51.9\%, en Irlanda del Norte fue tan sólo de un $44.2 \%$, siendo el $55.8 \%$ de los votos válidos emitidos favorables a permanecer en la Unión Europea. Ver: https://www.electoralcommission.org.uk/find-information-by-subject/elections-and-referendums/past-elections-and-referendums/eu-referendum/electorate-and-count-information
}

(3) GODDEN, Andrew; McCORMICK, Conor, "A new relationship? Brexit, Republic of Ireland and Northern Ireland", Constitutional Conversations, 3/6, Royal Irish Academy and Queen's University Belfast, 2016.

(4) CENTRE FOR CROSS BORDER STUDIES, «Briefing Paper1:The UK Referendum on Membership of the EU: What does it mean for us?", EU Referendum Briefing Papers, 2016, p. 6. Ver: http://www. cooperationireland.org/media/2298/ccbs_ci-eu-referendum-briefing-paper.pdf 


\section{El estatus jurídico-político de Irlanda del Norte}

Como es sabido, el estatus actual de Irlanda del Norte nace del Acuerdo de Paz de Viernes Santo (5), celebrado el día 10 de abril de 1998. Aquel día, las principales fuerzas políticas de Irlanda del Norte, amparadas por los gobiernos de Londres y Dublín, alcanzaron un acuerdo sobre el futuro político de dicho territorio y sobre el final de la ocupación militar británica, comprometiéndose con las vías pacíficas y democráticas para solucionar sus divergencias políticas. Comenzaron así a poner fin, no sin dificultades, a décadas de sufrimiento y conflicto armado (conocidas como The Troubles) (6).

A dicho acuerdo político se le adjuntó como anexo un tratado internacional acordado por los gobiernos de Irlanda y el Reino Unido, en el que ambos ejecutivos se comprometían a respetar la libre decisión de los ciudadanos de Irlanda del Norte en relación a su estatus político.

Y meses más tarde, para cerrar aquel primer ciclo de acuerdos, llegaría la Northern Ireland Act (en adelante NI Act) (7), que no es sino la traducción legal del acuerdo multipartidario. Se trata de la ley que posibilitó restaurar y actualizar el autogobierno de Irlanda del Norte, así como la transferencia de competencias (devolution), tras décadas de gobierno directo (direct rule) por parte de Westminster.

\section{El reconocimiento del derecho de autodeterminación como solución al conflicto político y armado}

El Acuerdo de Paz de Irlanda del Norte es un acuerdo multipartidario de carácter global que recoge múltiples aspectos, entre los cuales se pueden citar institucionalización y competencias, derechos y garantías (8), víctimas, presos y desarme, policía y justicia, y un largo etc. Para el ob-

(5) Su nombre oficial es "The Northern Ireland Peace Agreement», aunque es popularmente conocido como "Good Friday Agreement" (por los republicanos) o "Belfast Agreement" (por los unionistas). Ver: https://www.gov.uk/government/uploads/system/uploads/attachment_data/file/136652/ agreement.pdf

(6) Para una explicación breve del origen histórico-político del conflicto armado: BRUCE, Alan, "The fractured island: Divided sovereignity, identity and politics in Ireland", Journal of Conflictology, 4 (2), 2013, pág. 16 y ss. CRUSET, María Eugenia, "El Acuerdo de Viernes Santo y su realidad hoy", Revista Contemporánea, 1, 1, 2011, pp. 78-93. Sobre las vías para la paz: FITZDUFF, Mari, Más allá de la violencia. Procesos de resolución de conflicto en Irlanda del Norte, Bakeaz, Bilbao, 1998. ALONSO, Rogelio, Una historia de guerra y la búsqueda de la paz, Editorial Complutense, Madrid, 2001.

(7) Ver: https://www.legislation.gov.uk/ukpga/1998/47/contents

(8) En relación a los DDHH y el Acuerdo de Viernes Santo: CAIRA, Rocco, «El Acuerdo de Viernes Santo y los Derechos Humanos", Cuadernos de Deusto de Derechos Humanos, 45, Universidad de Deusto, Bilbao, 2007. 
jeto de este escrito, lo más relevante desde un punto de vista constitucional parece ser la adhesión de todos los partidos firmantes al compromiso adquirido por los gobiernos británico e irlandés de respetar lo que libremente pudiera decidir la ciudadanía norirlandesa con respecto a su futuro político (9); y en concreto:

1) Reconocer la legitimidad de la libre decisión de la ciudadanía norirlandesa con respecto a su estatus político, cualquiera que esta sea; es decir, ya sea para apoyar la unión con el Reino Unido como una Irlanda unida y soberana.

2) Reconocer que es en exclusiva a la ciudadanía de la isla de Irlanda a quien corresponde ejercer su derecho a la libre determinación (sic.) por acuerdo libre y simultaneo del norte y sur de la isla y contando siempre con el consentimiento de la mayoría de la ciudadanía de Irlanda del Norte.

3) Reconocer que el deseo actual (en 1998) de la mayoría de la ciudadanía de Irlanda del Norte es mantener la Unión con Gran Bretaña y que por tanto su estatus actual (en 1998) refleja y se basa en dicha voluntad; y que sería incorrecto realizar cualquier cambio en el estatus de Irlanda del Norte si no es con el consentimiento de la mayoría de su pueblo(10) (la cursiva es propia, y se destaca por la importancia posterior que tiene esta frase para el presente análisis).

4) Afirmar que si el pueblo de la isla de Irlanda en un futuro ejerce su derecho a la autodeterminación será obligación de ambos gobiernos introducir y apoyar en sus parlamentos la legislación necesaria para hacer efectiva dicha voluntad.

Como se ve, la clave de bóveda del acuerdo de paz es el reconocimiento del derecho de autodeterminación de los pueblos, y todas las fuerzas políticas, así como los gobiernos irlandés y británico, se comprometieron aquel día a respetar lo que la ciudadanía norirlandesa libremente pudiera decidir.

Además, el ordenamiento jurídico vigente en ningún caso sería obstáculo para dar cauce al deseo popular, ya que, tras el acuerdo, ambos gobiernos quedaron obligados a hacer las modificaciones legales necesarias que reflejasen dicha voluntad(11).

(9) «The Northern Ireland Peace Agreement», 2. Constitutional Issues, pág. 3.

(10) «....and that it would be wrong to make any change in the status of Northern Ireland save with the consent of a majority of its people», idem.

(11) Salvando las distancias tanto geográficas como políticas, creemos que se marca aquí una diferencia muy notable, por ejemplo, con lo que viene sucediendo en Catalunya en los últimos años, donde el Gobierno español viene parapetándose de forma continua en una legislación vigente que se niega a modificar, para defender así que los independentistas persiguen un imposible jurídico. 
Como anexos a este punto del acuerdo que recoge las cuestiones constitucionales, se adjuntaron unas propuestas de cláusulas a incorporar en la legislación británica y una propuesta de enmienda a la Constitución Irlandesa que diesen rúbrica jurídica al acuerdo de paz. Así, si mediante las primeras se reiteraba el compromiso de respetar lo que la ciudadanía norirlandesa libremente decidiera, y a su vez, se derogaba la Government of Ireland Act de 1920, mediante la segunda se retiró la reivindicación territorial sobre Irlanda del Norte presente en los artículos 2 y 3 de la Constitución irlandesa (proponiendo una redacción alternativa) (12) y se agregó al artículo 29 del mismo texto el compromiso de estado de quedar ligado por el acuerdo y respetar la voluntad del pueblo irlandés en sus dos jurisdicciones (la cursiva es propia y se destaca por la importancia).

\section{La Northern Ireland Act: transferencia de competencias y mapa institucional}

La NI Act viene a ser, desde su aprobación el 19 de noviembre de 1998, la principal herramienta de autogobierno con la que cuenta Irlanda del Norte, algo así como su estatuto de autonomía (aunque se trata de una ley aprobada no por la Asamblea de Irlanda del Norte sino por el Parlamento del Reino Unido(13)).

Esta ley es la que fija su estatus político actual, la que fija las bases para la devolution(14), y la que establece sus facultades tanto legislativas como ejecutivas, sus instituciones, su sistema de financiación o diversas materias relativas a derechos humanos. Su desarrollo no ha sido nada sencillo ni carente de complicaciones o atascos (incluso en la actualidad), por lo cual han sido necesarios varios acuerdos adicionales para desbloquear la situación y facilitar su implementación. Tal vez el

(12) Artículos 2 y 3 de la Constitución Irlandesa (en su redacción previa a 1998): Artículo 2: El territorio nacional consiste en la totalidad de la isla de Irlanda, sus islas adyacentes y el mar territorial. Artículo 3: Hasta la total reconstitución del territorio nacional, y sin perjuicio del derecho del Parlamento y del Gobierno, establecido por esta Constitución, a ejercer jurisdicción sobre la integridad de dicho territorio, las leyes de dicho Parlamento tendrán el mismo ámbito y alcance de aplicación que las leyes del Estado Libre de Irlanda (Saorstat Eireann) y el mismo efecto extraterritorial.

(13) Siendo la soberanía parlamentaria un principio fundamental del derecho constituticional británico, como parlamento soberano que es, el Parlamento Británico retiene la facultad de enmendar las Devolution Acts. DOUGLAS-SCOTT, Sionaid, "A UK exit from the EU:The end of the United Kingdom or a new constitutional dawn?», Legal Research Paper Series, Oxford University, March 2015, pág. 4.

(14) Definida como "...the creation of subordinate legislatures and assemblies». BOGDANOR, The New British Constitution, OUP, Oxford, 2009. 
más conocido de todos ellos sea el de St. Andrews (Escocia) en los años 2006-2007 (15); acuerdo que puso fin a la crisis de autogobierno que se vivía entonces.

La ley comienza por establecer el estatus de Irlanda del Norte como territorio del Reino Unido, fijando que dicha pertenencia sólo se verá alterada con el apoyo de una mayoría ciudadana en Irlanda del Norte y estableciendo un procedimiento para ello (art. 1). Además, queda derogada la Ley de Gobierno de Irlanda (16) de 1920 (art. 2) y se establece el modo en que el Secretario de Estado, siempre que considere que se ha progresado en la implementación del acuerdo de paz, puede presentar un proyecto de orden de transferencia (devolution) de facultades legislativas o ejecutivas (art. 3).

A tal efecto, la norma clasifica las competencias en materias exceptuadas, reservadas y transferidas (art. 4) (17).

1) Las materias exceptuadas serían aquellas que quedan fuera de toda posibilidad de transferencia y las más intrínsecamente unidas a la soberanía del estado (Corona, Parlamento del Reino Unido, Defensa, control de armas nucleares, químicas o de destrucción masiva, nacionalidad ). Para los efectos de este escrito, lo que interesa destacar es que se encuentra entre este tipo de materias, en tercer lugar, todo el tema de las relaciones internacionales, incluyendo las relaciones con las distintas instituciones europeas (18).

2) Las materias reservadas serían aquellas que en principio se reserva el estado, pero que no excluyen su futura transferencia a Irlanda

(15) En Saint Andrew's se puso fin a la crisis de autogobierno que se vivía entonces, con un acuerdo entre los Gobiernos de Londres y Dublín y el compromiso de los principales partidos de Irlanda del Norte: «The St. Andrew's Agreement (October 2006), published by the UK and Irish Governments following negotiations with all of the Northern Ireland parties, included a timetable leading towards the restoration of devolution and power-sharing in Northern Ireland. It required full acceptance of the PSNI by all parties as well as the restoration of the Northern Irish Assembly and a commitment by all parties to power sharing in the Executive. It included a plan to devolve policing and justice within two years of the restoration of the Executive. A new devolved administration was established in 2007, in which the Democratic Unionist Party served for the first time since the establishment of the institutions, and policing and justice were devolved in 2010». NORTH-SOUTH INTERPARLIAMENTARY ASSOCIATION, "Paper 1: Impact of Brexit on cross-border activity", Northern Ireland Assembly and Houses of the Oireachtas, 18/11/2016.

(16) Government of Ireland Act (1920).

(17) Excepted, reserved and transferred matters.

(18) 3. International relations, including relations with territories outside the United Kingdom, the European Communities (and their institutions) and other international organisations, and international development assistance and co-operation, but not- (a) the surrender of fugitive offenders between Northern Ireland and the Republic of Ireland; (...). (Northern Ireland Act / Schedule 2.3) 
del Norte. En este caso, se trata de materias como la navegación (excluyendo puertos y aguas interiores), la aviación civil, domicilio, correos, derecho penal, orden público, armas y explosivos, loterías, protección de datos y un largo etc. (19).

3) Y finalmente estarían las materias transferidas, que por exclusión, según se afirma en la norma, son aquellas que ni son exceptuadas ni son reservadas (art. 4.1).

Dicho lo anterior, nada impide que una materia reservada sea transferida, ni que una transferida vuelva a ser reservada (art. 4.2), para lo cual se establece un procedimiento concreto dependiente del Secretario de Estado.

En cuanto al mapa institucional, la norma viene a dar rango de ley al mapa institucional diseñado en el Acuerdo de Viernes Santo. Así, se organiza un sistema político parlamentario con un Ejecutivo que gira en torno a dos figuras principales, el Primer Ministro y el Primer Ministro Adjunto, elegidos ambos por la Asamblea legislativa y que han de actuar conjuntamente en numerosas decisiones (está regulado en la Parte III de la norma). Junto al Ejecutivo, se regula extensamente la Asamblea Legislativa de Irlanda del Norte (Parte IV). Y finalmente, se regulan también distintas instituciones surgidas del Acuerdo de Paz de Viernes Santo, como son el Consejo Ministerial Norte-Sur (que reúne a responsables de los ejecutivos del norte y sur de Irlanda para ser consultados, cooperar y actuar en materias de interés mutuo, siempre dentro de las competencias de cada cual); el Consejo Británico-Irlandés (que reúne a autoridades británicas e irlandesas junto con aquellas de Escocia, Gales e Irlanda del Norte para fomentar la cooperación en materias de interés mutuo); la Conferencia Intergubernamental Británico-Irlandesa (que reúne a los gobiernos británico e irlandés para promover la cooperación bilateral en materias de mutuo interés) o el Foro Cívico que asesora en materia económica, social o cultural (Parte V).

Las competencias que ostentan las instituciones de Irlanda del Norte son, como se puede bien apreciar, bastante limitadas; y además, la norma establece de forma meridianamente clara que:

- Uno: cualquier proyecto de ley aprobado por la Asamblea no llegará a ser ley si la materia regulada se encuentra fuera de sus competencias (art. 6).

-Y dos: el Secretario de Estado está facultado para: (1) Ordenar directamente que se impida a los gobernantes de Irlanda del Norte ejecutar cualquier acción (entiéndase por acción dictar normas con

(19) Northern Ireland Act / Schedule 2. 
rango inferior a la ley o presentar un proyecto de ley) que pudiera ser contraria a las obligaciones internacionales adquiridas por el Reino Unido, pudiendo incluso revocarla; o (2) Ordenar a las autoridades de Irlanda del Norte cualesquiera acciones que se considerasen necesarias para dar cumplimiento a las obligaciones internacionales adquiridas por el Reino Unido (art. 26).

Todo lo anterior conduce a concluir dos cosas con respecto al estatus político de Irlanda del Norte:

- La primera; que Irlanda del Norte tiene plena capacidad de decidir su futuro. Es decir, que es titular, junto con el sur de la isla, del derecho de autodeterminación de los pueblos (no siendo la autodeterminación un mero principio político sino un verdadero derecho).

- La segunda; que sin embargo, hoy por hoy sigue contando con unas instituciones de autogobierno bastante limitadas y dependientes de Londres.

\section{El Brexit y sus implicaciones jurídico-constitucionales}

Una vez explicado el actual estatus de Irlanda del Norte, y teniendo en cuenta que una mayoría holgada de ciudadanos y ciudadanas norirlandesas apuesta por permanecer dentro de la UE (un 55.8\% apoyó el remain en el referéndum(20)), cabe hacerse varias preguntas: ¿Se le podría dar cauce legal al deseo ciudadano? Es decir, ¿Puede Irlanda del Norte, de alguna manera, frenar su salida de la UE? ¿Cuenta con herramientas legales para ello? ¿Acaso no dice el Acuerdo de Viernes Santo que no se hará ningún cambio de estatus en Irlanda del Norte sin el apoyo de su ciudadanía? Entonces, ¿Tienen las ciudadanas y ciudadanos de este territorio alguna posibilidad de frenar el Brexit?

Son todas ellas cuestiones discutibles y, de hecho, así ha venido sucediendo tanto en el terreno político como en el jurídico. Sin embargo, si a lo que se atiende es a las resoluciones judiciales la conclusión es clara: No. Esa es por lo menos la posición que mantuvieron tanto la Corte Superior de Belfast en octubre de 2016 (21) como la Corte Suprema del

(20) Ver: https://www.electoralcommission.org.uk/find-information-by-subject/elections-and-referendums/past-elections-and-referendums/eu-referendum/electorate-and-count-information

(21) McCord's (Raymond) Application [2016] NIOB 85: https://www.courtsni.gov.uk/en-GB/Judicial\%20Decisions/PublishedByYear/Documents/2016/\%5B2016\%5D\%20NIQB\%2085/j_j_MAG10076Final.htm 
Reino Unido en enero de 2017 (22), en sendas sentencias que dieron respuesta a varios recursos interpuestos aquellos días contra el Brexit.

\section{Los recursos contra el Brexit y la sentencia de la High Court de Belfast}

Tras conocerse los resultados del referéndum favorables al Brexit y, sobre todo, la posición dominante que el Gobierno de Londres tendría en su negociación, en Irlanda del Norte se pusieron en marcha sendos recursos judiciales (McCord y Agnew And Others), argumentando que se incumplía el principio de consentimiento y que se incumplía el derecho de la Asamblea a proteger las garantías del proceso de paz previstas en el Acuerdo de Viernes Santo (23).

Se argumentó, entre otras cosas, que la notificación a que hace referencia el art. 50 TUE(24), mediante la cual un Estado manifiesta formalmente su deseo de abandonar la UE y pone formalmente en marcha dicho proceso, sólo podía darse vía Ley del Parlamento (Act of Parliament) y no vía gubernativa mediante prerrogativa real de un ministro (Royal Prerrogative), ya que a pesar de que la materia relativa a relaciones internacionales era competencia del Gobierno, éste no tenía autorización para modificar el ordenamiento jurídico interno si no era con el consentimiento del Parlamento.

(22) JUDGMENT R (on the application of Miller and another) (Respondents) $v$ Secretary of State for Exiting the European Union: https://www.supremecourt.uk/cases/docs/uksc-2016-0196-judgment.pdf

(23) El primer recurso fue interpuesto por el señor Raymond McCord, víctima del conflicto político y armado, cuyo hijo fue asesinado por paramilitares lealistas en 1997. El segundo fue interpuesto por una pluralidad de recurrentes, entre los cuales había políticos y miembros de la Asamblea de Irlanda del Norte (Agnew and Others). Se puede encontrar un buen resumen del contenido de ambos en: NORTH-SOUTH INTERPARLIAMENTARY ASSOCIATION, "Paper 1: Impact of Brexit on...», op. cit., pág. 22 y ss.

(24) Artículo 50TUE: 1. Todo Estado miembro podrá decidir, de conformidad con sus normas constitucionales, retirarse de la Unión. 2. El Estado miembro que decida retirarse notificará su intención al Consejo Europeo. A la luz de las orientaciones del Consejo Europeo, la Unión negociará y celebrará con ese Estado un acuerdo que establecerá la forma de su retirada, teniendo en cuenta el marco de sus relaciones futuras con la Unión. Este acuerdo se negociará con arreglo al apartado 3 del artículo 218 del Tratado de Funcionamiento de la Unión Europea. El Consejo lo celebrará en nombre de la Unión por mayoría cualificada, previa aprobación del Parlamento Europeo. 3. Los Tratados dejarán de aplicarse al Estado de que se trate a partir de la fecha de entrada en vigor del acuerdo de retirada o, en su defecto, a los dos años de la notificación a que se refiere el apartado 2, salvo si el Consejo Europeo, de acuerdo con dicho Estado, decide por unanimidad prorrogar dicho plazo. 4. A efectos de los apartados 2 y 3, el miembro del Consejo Europeo y del Consejo que represente al Estado miembro que se retire no participará ni en las deliberaciones ni en las decisiones del Consejo Europeo o del Consejo que le afecten. La mayoría cualificada se definirá de conformidad con la letra b) del apartado 3 del artículo 238 del Tratado de Funcionamiento de la Unión Europea. 5. Si el Estado miembro que se ha retirado de la Unión solicita de nuevo la adhesión, su solicitud se someterá al procedimiento establecido en el artículo 49. 
Consecuentemente, al resultar necesaria una ley del Parlamento de Westminster para poner en marcha el proceso de desconexión de la UE, se razonó que resultaba también necesario el consentimiento legislativo de la Asamblea de Irlanda del Norte, ya que así estaba establecido para la legislación que afectase a poderes transferidos (devolved powers) según la Convención de Sewel o Sewel Convention(25).

Conviene aclarar aquí que Sewel Convention es el término coloquial mediante el cual se denomina a la política de estado respecto a legislación británica referente a materias transferidas, en virtud de la cual, es necesario el consentimiento del Parlamento regional correspondiente para que Westminster pueda aprobar su legislación. Surgió en relación a Escocia, pero a día de hoy se entiende aplicable a todas las devolved regions, y debe su particular nombre a Lord Sewel, antiguo Ministro de Estado para Escocia.

Hecho el inciso, prosigamos con los argumentos de los recurrentes. Argumentaron también que la Oficina de Irlanda del Norte (en inglés Northern Ireland Office(26)) no había respetado lo recogido en el art. 75 de la NI Act, que establece que se ha de realizar una evaluación previa de la igualdad del impacto de cualquier legislación aplicable en Irlanda del Norte para garantizar que no hay discriminación por creencias religiosas, opinión política, grupo racial, orientación sexual, etc. (lo que se conoce como equality assessment). Según manifestaron, este no se había realizado en lo que respectaba al artículo 50TUE, aun cuando resultaba preceptivo hacerlo.

Afirmaron a su vez que el Acuerdo de Viernes Santo creaba una expectativa subjetiva legítima de que no se realizaría ningún cambio en el estatus de Irlanda del Norte sin el consentimiento de su ciudadanía, y sin embargo, el abandono de la UE generaba un evidente cambio de estatus político contrario al deseo de una mayoría ciudadana en esta región.

Por último, y estrechamente ligado a todo lo anterior, argumentaron que la NI Act estaba intrínsecamente ligada a la pertenencia a la UE del Reino Unido, que la salida de la UE sin consentimiento parlamentario suponía una restricción arbitraria de los derechos de los ciudadanos, y que el Brexit socavaba tanto el Acuerdo de Viernes Santo como la NI Act, ya que ambos contenían diversos aspectos relativos al derecho comunitario (por ejemplo, la protección de derechos fundamentales) (27).

(25) Para consultar un análisis de la misma: BOWERS, Paul, "The Sewel Convention», House of Commons Library, 25 November 2005. Disponible en la web de la Cámara de los Comunes: http://researchbriefings.parliament.uk/ResearchBriefing/Summary/SN02084

(26) Se trata de un Ministerio del Gobierno Británico encargado de los asuntos de Irlanda del Norte, y a cuyo frente está un miembro del Gabinete. Ver: https://www.gov.uk/government/organisations/ northern-ireland-office

(27) TONGUE, Jonathan, "The Impact and Consequences of Brexit for Northern Ireland", Constitutional Affairs, European Parliament, 2017, pp. 2-3. 
Ambos recursos llegaron ante la High Court de Belfast, quien decidió resolverlos de forma conjunta considerando la urgencia que tenían las cuestiones planteadas (28), y lo hizo para desestimar las pretensiones de los recurrentes.

En concreto, la Corte estableció que no hacía falta ninguna intervención parlamentaria para la notificación a que hace referencia el art. 50 TUE, por entenderlo comprendido en el poder de prerrogativa del Gobierno. Estableció a su vez que el valor de la Convención de Sewel era meramente político y por lo tanto no exigible jurídicamente, por lo cual no era jurídicamente exigible el consentimiento de la Asamblea de Irlanda del Norte para activar dicho proceso. Afirmó también que no había habido violación alguna del art. 75 de la NI Act por parte de la Oficina de Irlanda del Norte. Y finalmente, sentenció que las referencias al consentimiento de la ciudadanía de Irlanda del Norte con respecto a su futuro político contenidas en los acuerdos de paz lo eran en relación a la pertenencia al Reino Unido o a Irlanda, pero no en relación a otros tipos de cambio de estatus como podía ser el abandono de la UE (29).

\section{La Sentencia de la Corte Suprema del Reino Unido sobre el Brexit}

De todas formas, la cosa no acabó en Belfast. Quien finalmente dirimió la cuestión que nos ocupa fue la Corte Suprema del Reino Unido, que acumuló las apelaciones presentadas contra la sentencia de la High Court de Belfast en el caso McCord y contra la Sentencia de la High Court de Inglaterra y Gales que daba respuesta a las demandas de Gina Miller y Deir Tozetti Dos Santos.

Se ha de decir que la sentencia, independientemente de si se está de acuerdo con ella o no, resulta toda una lección magistral de derecho

\footnotetext{
(28) «[6] The applications for judicial review have been considered together. Because of their urgency, the court has dealt with them under an expedited timetable. The hearing before the court has taken the form of a rolled up hearing so that the court technically has before it both the issue of leave to apply for judicial review and the issue of appropriate relief in the event that leave to apply for judicial review is gran ted". McCord's (Raymond) Application [2016] NIQB 85.

(29) «[153] While it is correct that section 1 of the 1998 Act does deal with the question of the constitutional status of Northern Ireland it is of no benefit to the applicant in respect of the question now under consideration as it is clear that this section (and the relevant portion of the Good Friday Agreement) is considering the issue only in the particular context of whether Northern Ireland should remain as part of the United Kingdom or unite with Ireland. The very fact that the issue is dealt with in this way, it seems to the court, makes it unlikely that the applicant's wider view as to the meaning of these provisions can be correct». McCord's (Raymond) Application [2016] NIQB 85.
} 
constitucional e historia del derecho del Reino Unido, y sin lugar a dudas, merece la pena estudiarla, por ser «tan brillante y bien construida (30)».

\subsection{La CUestión PRINCIPAL: Gobierno vs. PARLAMENTO. IMPLicaciones del PRINCIPIO DE SOBERANÍA PARLAMENTARIA}

La cuestión común en ambos recursos era dirimir si un ministro, sin consentimiento previo del Parlamento de Westminster, podía activar el proceso de abandono de la UE o no, así que esa fue la primera y principal cuestión que resolvió la Corte, para lo cual analizó tanto la European Communities Act de 1972 (en adelante EC Act) como las prerrogativas reales de los ministros del Reino Unido(31).

Las posiciones principales ante tal cuestión eran dos. Según el secretario de Estado, los ministros tenían dicho poder en relación con los Tratados de la UE, y por lo tanto no era necesaria autorización previa por parte del Parlamento para notificar la voluntad de salida de la UE. Para los demandantes, por el contrario, la notificación introducía al Reino Unido en

(30) BUSTOS GISBERT, Rafael, «La desnudez de la Constitución británica. Crónica marciana de la Sentencia de la Corte de Justicia del Reino Unido de 24 de enero de 2017", Revista Española de Derecho Europeo, 62, abril-junio de 2017, pp. 13-46.

(31) Para algunos autores el problema real no era si el Gobierno podía notificar o no la voluntad de salida, sino que no había una decisión formal por parte del Reino Unido de abandono de la UE (por lo menos a fecha 27 de octubre de 2016), ya que en base al principio de soberanía parlamentaria esa decisión correspondía sólo al parlamento, y en consecuencia, el referéndum celebrado no podía suplir su intervención. "Ever since the debate about the respective roles of parliament and government in the Brexit process gathered steam, there has been an excessive focus on the notification question: is it for the government to 'trigger' Article 50 by notifying the EU, or is it for parliament? This kind of framing of the debate overlooks the wording of Article 50. The first paragraph of that provision proclaims that 'any Member State may decide to withdraw from the Union in accordance with its own constitutional requirements'. The second paragraph states that 'a Member State which decides to withdraw shall notify the European Council of its intention'. So first, there must be a constitutionally orthodox decision to withdraw. The notification is secondary. The first paragraph of Article 50 distinguishes the article from standard treaty clauses governing termination. Those clauses usually conflate the withdrawal decision and its notification. They reflect a traditional international law and international relations paradigm, according to which foreign affairs are mostly a matter for the executive. The clauses themselves do not mention the executive, but they treat states as unitary actors, and the practice is simply that the state expresses itself internationally through executive action. It is the government which acts on the international plane. How such executive action comes about as a matter of domestic law is irrelevant, except in blatant cases (see e.g. Art 46 on provisions of internal law regarding competence to conclude treaties). By contrast, Article 50 expressly requires that there is first an internal decision to withdraw, adopted in accordance with the member state's own constitutional requirements. Once that decision has been taken, the member state must notify, and I have no issues whatsoever with the position that this is properly governmental action. Indeed, it is the European Council which needs to be notified, and that EU organ is itself composed of heads of state and government. Nor would I argue that it is for anyone else than the member state concerned to determine what its own constitutional requirements are, for taking the withdrawal decision. The other member states and the EU institutions do not, on the face of things, have the power to review whether the withdrawal decision is constitutionally orthodox». EECKHOUT, Piet, "The UK decision to withdraw the EU: parliament or government?". Ver: https://constitution-unit. com/2016/10/27/the-uk-decision-to-withdraw-from-the-eu-parliament-or-government/ 
un camino de no retorno, ya que, independientemente de que se derogase o no la EC Act de 1972, gran parte de la legislación de la UE dejaría de tener efecto (32), por lo cual la autorización parlamentaria vía Act of Parliament era preceptiva (párrafo 36 de la sentencia).

El Tribunal comenzó su análisis diciendo algo que es sabido: el Reino Unido no tiene una constitución entendida como un único código coherente que prevalece sobre el resto del ordenamiento, sino que se trata de un conjunto de leyes, hechos, convenciones, escritos académicos y decisiones judiciales que han ido evolucionando en el tiempo. Así, explicó, si originalmente la soberanía residía en el monarca y por tanto éste ejercía todos los poderes del estado, con el paso de los siglos esos poderes, conocidos como las prerrogativas reales, fueron reducidos mediante la transición a una monarquía parlamentaria y un estado de derecho. Y para finales del siglo $\mathrm{xx}$, prácticamente todas esas prerrogativas reales se habían repartido ya entre los 3 principales poderes del Estado: ejecutivo, legislativo y judicial (párrafo 41).

Dicho lo anterior, la Corte recordó que a día de hoy la soberanía británica reside en el Parlamento; es decir, que la soberanía parlamentaria (33) es principio fundamental de la Constitución Británica (párrafo 43). Los jueces se ocupan de desarrollar la common law (párrafo 42) y el poder administrativo (o ejecutivo) de la Corona se ejerce por el Gobierno; pero este último es controlado por el Parlamento y además ha de respetar siempre tanto las leyes como la common law, no pudiendo ni cambiarlas ni infringirlas (párrafo 45).

Avanzando en su explicación y haciendo hincapié en la misma idea, la Corte manifestó que es principio fundamental del derecho constitucional británico que a menos que la legislación primaria o básica lo permita, la prerrogativa real no faculta a los ministros para cambiar el common law ni las leyes o statute law (párrafo 50 ).

50. Consistently with paras 44 to 46 , and the passage quoted from Professor Wade in para 47 above, it is a fundamental principle of the UK constitution that, unless primary legislation permits it, the Royal prerogative does not enable ministers to change statute law or common law. As Lord Hoffmann observed in $R$ (Bancoult) $v$ Secretary of State for Foreign and

\footnotetext{
(32) Se ha de tener en cuenta que independientemente de que haya acuerdo o no sobre el Brexit, el Reino Unido dejará de formar parte de la UE en un plazo máximo de dos años tras la notificación a que hace referencia el art. 50TUE.

(33) Sobre el concepto de soberanía parlamentaria en la Constitución del Reino Unido: HESTERMAYER, Holger P., «How Brexit will happen: A Brief Primer on EU Law and Constitutional Law Questions Raised by Brexit»; Journal of International Arbitration, King's College, London, 2016, pág. 6 y ss.
} 
Commonwealth Affairs (No 2) [2009] AC 453, para 44, "since the 17th century the prerogative has not empowered the Crown to change English common or statute law». This is, of course, just as true in relation to Scottish, Welsh or Northern Irish law. Exercise of ministers' prerogative powers must therefore be consistent both with the common law as laid down by the courts and with statutes as enacted by Parliament.

Una vez aclarado lo anterior, afirmó que el ámbito más importante en el que los ministros ejercen la prerrogativa real es dirigir los asuntos exteriores del Reino Unido, lo cual (en relación al anterior párrafo) no significaría que su utilización no pueda tener consecuencias jurídicas internas; las puede tener, pero no puede cambiar el derecho británico (párrafo 52).

Se incluirían bajo esta prerrogativa las relaciones diplomáticas, el despliegue de las fuerzas armadas en el extranjero y, particularmente en lo que respecta al caso, la elaboración de tratados. Según manifestó el Alto Tribunal, existe hasta la fecha poca jurisprudencia sobre el poder de rescindir o retirarse de los tratados, pero, "como cuestión de lógica y de necesidad práctica", afirmó, "debe formar parte de la prerrogativa que confiere el tratado" (párrafo 54).

Dicho ello, y sin perjuicio de las restricciones impuestas por la legislación primaria, la regla general según el Tribunal es que el poder de formular o deshacer los tratados puede ejercerse sin autoridad legislativa y que el ejercicio de esa facultad no puede ser revisado por los tribunales. Este principio se basaría en la llamada teoría dualista, fundamentada en la proposición de que el derecho internacional y el derecho interno funcionan en esferas independientes.

El poder de hacer/deshacer tratados dependería, según la Corte, de dos proposiciones relacionadas.

- La primera; que los tratados entre Estados soberanos tienen efecto en el derecho internacional y no se rigen por el derecho interno de ningún Estado.

- La segunda; que aunque son vinculantes para el Reino Unido en el derecho internacional, los tratados no forman parte de la legislación del Reino Unido y no dan lugar a derechos u obligaciones legales en el derecho interno (párrafo 55).

Sólo sobre la base de estas dos proposiciones se desprendería que el ejercicio del poder de hacer y deshacer los tratados es compatible con la regla de que los ministros no pueden alterar el derecho interno del Reino Unido (párrafo 56), y por lo tanto, se podría afirmar que el sistema dualista es un corolario necesario de la soberanía parlamentaria, que existe para proteger no a los ministros sino al Parlamento (párrafo 57). 
Sin embargo, eso que ocurre en el Reino Unido con el derecho internacional no es exactamente igual con el derecho comunitario. De hecho, resulta más bien al contrario, ya que en base a la EC Act de 1972 (que es legislación interna), el derecho comunitario es fuente de derecho del Reino Unido y ha sido fuente de derechos para su ciudadanía (La Corte lo analizó profusamente en lo párrafos 60-115). Es decir, está fuertemente incrustado en distintos aspectos del derecho interno y, al ser esto así, la retirada de la UE estaría precipitando una modificación del mismo, por lo que los ministros no podrían alegar tener prerrogativa real para realizar la notificación prevista en el artículo 50TUE. Para poder hacer dicha notificación necesitaría pues autorización previa del Parlamento, y así lo expresaron los jueces:

101. Accordingly, we consider that, in light of the terms and effect of the 1972 Act, and subject to considering the effect of subsequent legislation and events, the prerogative could not be invoked by ministers to justify giving Notice: ministers require the authority of primary legislation before they can take that course.

Dicho ello, para terminar de resolver esta primera cuestión la Corte analizó finalmente si la European Union Referendum Act de 2015 y el resultado del referéndum de 2016 cambiaban en algo lo dicho, ya que en base a dicha ley (aprobada como todas por el Parlamento), el pueblo del Reino Unido sí que había otorgado permiso para abandonar la UE.

De hecho, esa era más o menos la postura del Procurador General, que sostuvo que "la opinión tradicional sobre los límites del poder de prerrogativa no debería aplicarse a una decisión ministerial autorizada por la mayoría de los miembros del electorado que voten en un referéndum previsto por el Parlamento". En efecto, dijo que aunque fue el Parlamento quien requirió el referéndum, la respuesta al mismo debería ser competencia de los ministros y no debería verse limitada por las limitaciones legales que se hubieran aplicado en ausencia del mismo (párrafo 116).

La Corte en cambio no le dio la razón, y antes de entrar de lleno a resolver ese debate, afirmó dos cosas en relación a esta ley. Primero, asumió que el referéndum era un mecanismo bastante nuevo en el derecho constitucional británico, por lo cual no existía mucha jurisprudencia donde apoyarse. Y segundo, añadió que la ley de referéndum de 2015 no establecía si se estaba ante un referéndum consultivo o vinculante. Los políticos habían hecho manifestaciones contradictorias en ese sentido, pero a fin de cuentas no eran más que eso, meras manifestaciones y no leyes del Parlamento (párrafo 119). 
El Secretario de Estado había sugerido que una vez remitida al electorado la cuestión de si abandonar o no la UE, el Parlamento no podía pensar que, en el caso de darse una respuesta afirmativa por parte del electorado, la misma pregunta sería remitida después al Parlamento. Pero la Corte no aceptó dicho argumento. Básicamente dijo, porque suponía asumir aquello que pretendía probar, es decir, que el Parlamento había fijado que el referéndum tenía efecto tanto político como jurídico (párrafo 120).

$\mathrm{Si}$, como era el caso, la aplicación del resultado del referéndum requería un cambio en la ley y la ley no había previsto ese cambio, dicha modificación debía hacerse de la única manera en que la Constitución del Reino Unido permite, a saber, a través de la legislación parlamentaria (párrafos 121 y 122), siendo competencia de éste decidir bajo qué forma.

Por lo tanto, ya que el referéndum de 2016 no cambió la ley en forma de permitir a los ministros retirar al Reino Unido de la Unión Europea sin legislación previa, correspondía al Parlamento autorizar al Gobierno.

Eso, afirmó la Corte, "de ninguna manera significa que el referéndum carece de efecto. Significa que, a menos que y hasta que el Parlamento actúe, su fuerza es más política que legal» (párrafo 124). Es precisamente lo que había establecido años antes el Comité Constitucional de la Cámara de los Lores a modo de recomendación: «Debido a la soberanía del Parlamento(34), los referendos no pueden ser jurídicamente vinculantes en el Reino Unido, por lo que son consultivos. Sin embargo, sería difícil para el Parlamento ignorar una expresión decisiva de la opinión pública» (párrafo125) (35).

Esta fue pues la forma en que zanjó definitivamente el Tribunal la primera cuestión, estableciendo de forma muy clara la supremacía del Parlamento británico en base al principio de soberanía parlamentaria(36).

(34) El principio de soberanía del Parlamento es básico en el constitucionalismo del Reino Unido. Se trata, en definitiva, del derecho a hacer y deshacer cualquier ley y, aún más, el derecho a que a ninguna persona se le reconozca el poder de inaplicar o anular la legislación del Parlamento. Sobre dicho principio, un clásico: DICEY, Albert Venn, Introduction to the Study of the Law of the Constitution, Liberty Classics, Indianapolis (USA), 1982, pp. 3-73. Ver: http://files.libertyfund.org/ files/1714/0125_Bk.pdf

(35) Parte de la doctrina también se pronuncia en el mismo sentido sobre la EU Referendum Act 2015: "The 2015 EU Referendum Act, which created the referendum, made no provisions for the consequences of the vote. Legally the referendum result could be ignored, but politically that would be nigh on impossible». FRENCH, Duncan, "Brexit: A Constitutional, Diplomatic and Democratic Crisis. A View from the Trenches", PER/PELJ 2016 (19), Potchefstroom (South Africa), 29 september 2016, pág. 8.

(36) Es lo que destacan Colin Harvey y Daniel Holder en las entrevistas realizadas. Lo cierto es que ya antes de la sentencia, buena parte de la doctrina se había manifestado en idénticos términos. Como ejemplo: DOUGLAS-SCOTT, Sionaidh, «Brexit, the referéndum and the UK Parliament: Some questions about sovereignty". Ver: https://ukconstitutionallaw.org/2016/06/28/sionaidh-douglas-scottbrexit-the-referendum-and-the-uk-parliament-some-questions-about-sovereignty/ 


\subsection{LA CUESTIÓN NORIRLANDESA EN RELACIÓN AL BREXIT}

Tras ello, y hay que decirlo, de forma mucho más breve, se puso a resolver las cuestiones específicas de Irlanda del Norte, que básicamente eran cinco (párrafo 126):

1) ¿Alguna de las disposiciones de la NI Act, el Acuerdo de Viernes Santo o el Tratado Británico-irlandés, obliga al Reino Unido a emitir legislación básica antes de que un ministro pueda realizar la notificación prevista en el art. 50 TUE?

2) Si la respuesta es afirmativa, ¿Se requiere el consentimiento de la Asamblea de Irlanda del Norte antes de promulgar la legislación pertinente?

3) Si la respuesta es negativa, ¿Se aplica alguna disposición de la $\mathrm{NI}$ Act, el Acuerdo de Viernes Santo o el Tratado entre Irlanda y Gran Bretaña como restricción del ejercicio de la facultad prerrogativa de notificar por parte de un ministro?

4) ¿El art. 75 de la NI Act impide el ejercicio de la facultad de notificar en ausencia del cumplimiento por parte de la Oficina de Irlanda del Norte de sus obligaciones recogidas en dicho artículo?

5) ¿La notificación sin el consentimiento del pueblo de Irlanda del Norte impide la aplicación del art. 1 de la Northern Ireland Act?

Como se ha explicado, la respuesta a la primera cuestión era afirmativa por lo que la tercera pregunta quedó automáticamente eliminada. Sin embargo, la Corte quiso dar alguna explicación adicional con respecto a la primera pregunta. Así, estableció que aun cuando la NI Act presumía que el Reino Unido seguiría siendo estado-miembro de la UE, y aun cuando se facultaba a las instituciones norirlandesas para aplicar la legislación comuntaria, la ley no iba más allá, y en ningún momento obligaba al Reino Unido a seguir perteneciendo a la UE. En el Reino Unido, recordó el Alto Tribunal, las relaciones con la Unión Europea, al igual que otras cuestiones de asuntos exteriores, están reservadas o exceptuadas en los casos de Escocia e Irlanda del Norte, y ni tan siquiera se reconocen en el caso de Gales (37) (párrafo 129).

En consecuencia, afirmó claramente la Corte, las cámaras legislativas territoriales «no tienen una competencia legislativa paralela en relación con la retirada de la Unión Europea». Las limitaciones sobre la UE establecidas en los ordenamientos descentralizados no son sino un medio por el cual el Parlamento y el Gobierno del Reino Unido se aseguran de

(37) Véase el artículo 30 1) Párrafo 7 (1) del Anexo 5 de la Ley de Escocia de 1998; El párrafo 4 del artículo 108 y la Parte 1 del Anexo 7 de la Ley del Gobierno de Gales de 2006; Y el párrafo 1 de la sección 4 y el párrafo 3 del Anexo 2 de la NI Act. 
que las instituciones democráticas territoriales no pongan al Reino Unido en contravención de sus obligaciones con el Derecho de la UE (párrafo 130).

Aclarado ello, la Corte dio respuesta a la segunda pregunta, que en esencia estaba hecha para aclarar el valor de la Sewel Convention. Como se ha explicado con anterioridad, se trata de una convención que fue adoptada como medio para establecer relaciones de cooperación entre el Parlamento Británico y las instituciones territoriales (donde podían existir y existían competencias legislativas superpuestas), estableciendo que para legislar sobre materias transferidas Westminster debía contar con la autorización previa de las asambleas territoriales.

Para la Corte había que tener clara una cosa desde el principio: a pesar de que el Reino Unido se ha ido descentralizando progresivamente en las últimas décadas, el Parlamento del Reino Unido siempre ha conservado intacto su derecho a legislar sobre asuntos que son de la competencia de una cámara legislativa territorial. Por ejemplo, el art. 5 de la NI Act faculta a la Asamblea de Irlanda del Norte para hacer leyes, pero el apartado 6 establece que ello «no afecta el poder del Parlamento del Reino Unido de hacer leyes para Irlanda del Norte» (38) (párrafo 136).

Dicho esto, añadió el Alto Tribunal, está claro que en el proceso de descentralización resulta beneficioso evitar choques, por lo que parece lógico que siempre que Westminster vaya a legislar sobre competencias transferidas, lo haga con la aprobación de la correspondiente asamblea territorial.

De eso trata la Sewel Convention, que como bien recordó la Corte, toma su nombre de Lord Sewel, quien en un debate en la Cámara de los Lores sobre la cláusula que ahora es sección 28 de la Ley de Escocia (2016), declaró en julio de 1998 que, si bien la desconcentración de la competencia legislativa no afectaba la capacidad del Parlamento del Reino Unido para legislar sobre Escocia, era esperable que se estableciera una convención para que Westminster normalmente no legislase con respecto a los asuntos descentralizados en dicha región sin el consentimiento del Parlamento escocés (expectativa que por cierto ha venido cumpliéndose durante años) (párrafo 137).

La convención, tal y como destacó la Corte, se plasmó en un Memorando de Entendimiento - Memorandum of Understanding (MoU)(39)-

(38) Lo mismo ocurre en Escocia y Gales: El artículo 28 (7) de la Ley de Escocia de 1998 establece que la sección que faculta al Parlamento escocés para hacer leyes: «no afecta el poder del Parlamento del Reino Unido para hacer leyes para Escocia». En el artículo 107 (5) de la Ley del Gobierno de Gales de 2006 se dispone sustancialmente idéntica para Gales.

(39) Un memorando de entendimiento (MOU) es un acuerdo no vinculante entre dos o más partes que describe los términos y detalles de un entendimiento, incluidos los requisitos y responsabilidades de cada parte. 
entre el Gobierno británico y los gobiernos descentralizados en diciembre de 2001, y siendo eso así, el párrafo 14 del actual Memorando de Entendimiento, publicado en octubre de 2013, dice: «El Gobierno del Reino Unido procederá de conformidad con la convención de que el Parlamento del Reino Unido normalmente no legislará con respecto a los asuntos descentralizados excepto con el acuerdo del parlamento territorial correspondiente. Las administraciones descentralizadas serán responsables de buscar el acuerdo que sea necesario (...) (40)» (párrafo 138).

Por lo tanto, el Gobierno del Reino Unido se comprometió a no solicitar ni apoyar la legislación pertinente en el Parlamento del Reino Unido sin el consentimiento previo de la cámara legislativa territorial correspondiente (consentimiento que es otorgado por una moción de consentimiento legislativo que el respectivo gobierno descentralizado introduce en la citada cámara). Sin embargo, y es un dato de vital importancia jurídica, el párrafo 2 del Memorando declaró que se trataba de una declaración de intención política y que no creaba obligaciones legales (párrafo 139), por lo que el Alto Tribunal dijo que no se le podía pedir que hiciera cumplir dicha convención, ya que la jurisprudencia al efecto era muy clara (párrafos 141 y 144) (41).

Las cámaras legislativas territoriales, recordó, han aprobado durante los últimos años mociones de consentimiento legislativo no sólo cuando el Parlamento del Reino Unido ha legislado sobre asuntos que caen dentro de la competencia legislativa de una cámara legislativa territorial, sino también cuando éste ha promulgado disposiciones que alteraban directamente la competencia legislativa de una cámara legislativa territorial o modificaban la competencia ejecutiva de las administraciones descentralizadas (42). Sin embargo, tal y como recordó la Corte, la legislación que implementa cambios en las competencias de las instituciones de la UE y afecta las competencias transferidas (como la Ley de 2008 que incorpora el Tratado de Lisboa por la que se modifican el TUE y el TFUE en el apartado 1 del artículo 2 de la Ley de 1972), no ha sido objeto de mociones de consentimiento legislativo en ningún parlamento territorial (párrafo 140), por lo que no cabía exigirlo ahora.

Además, según los jueces, "el artículo 9 de la Carta de Derechos (Bill of Rights), que establece que «las actuaciones en el Parlamento no deben

(40) SCOTTISH GOVERNMENT, «Memorandum of Understanding and Supplementary Agreements between the United Kingdom Government, the Scottish Ministers, the Welsh Ministers and Northern Ireland Executive Committee». Ver: http://www.gov.scot/Resource/0043/00436627.pdf

(41) En ese mismo sentido: REID, Paul, «Time to give Sewel Convention some (political) bite?». Ver: https://ukconstitutionallaw.org/2017/01/26/paul-reid-time-to-give-the-sewel-convention-some-political-bite/

(42) Por ejemplo, el Parlamento escocés aprobó las mociones de consentimiento legislativo antes de la promulgación de la Ley de Escocia de 2012 y la de 2016. 
ser impugnadas o cuestionadas en cualquier tribunal o lugar fuera del Parlamento", constituía una razón adicional por la cual los tribunales no podían pronunciarse sobre el funcionamiento de esta convención (párrafo 145).

Por lo tanto, la respuesta del Tribunal fue que el consentimiento previo de la Asamblea de Irlanda del Norte no era un requisito legal exigible ante los Tribunales (párrafo 150) (43).

En cuanto a la cuarta pregunta, es decir, si el art. 75 de la NI Act impide el ejercicio de la facultad de notificar en ausencia del cumplimiento por parte de la Oficina de Irlanda del Norte de sus obligaciones recogidas en dicho artículo, la respuesta también fue negativa. Dicho artículo 75 obliga a las autoridades públicas en el desempeño de sus funciones a promover la igualdad de oportunidades y realizar evaluaciones al efecto. Sin embargo, según dijo la Corte, en el apartado 3 se define «autoridad pública» para los fines del artículo, y a diferencia de otros casos (como el art. 76.7) no se incluye la figura de un Ministro de la Corona. Además, según el Tribunal, la decisión de retirada de la UE no se tomó en relación a Irlanda del Norte sino al conjunto del Reino Unido (párrafo 133).

Por último, la quinta pregunta también fue respondida en sentido negativo. Como se ha dicho, el artículo 1 de la NI Act establece que Irlanda del Norte forma parte del Reino Unido y que dicho estatus no cambiará más que con el consentimiento de la mayoría de su población, que pudiera decidir unificarse con Irlanda. A juicio del Tribunal, esta importante disposición, que surgió del Acuerdo del Acuerdo de Viernes Santo, dio a Irlanda del Norte el derecho de decidir si permanecería en el Reino Unido o si sería parte de una Irlanda unida, pero no regula ningún otro cambio en el estatus constitucional de Irlanda del Norte, ni requiere el consentimiento de la mayoría del pueblo de Irlanda del Norte para la retirada del Reino Unido de la Unión Europea (párrafo 135).

Es algo con lo que se ha mostrado completamente en desacuerdo el jurista y profesor Colin Harvey, para quien la pertenencia a la UE era algo que no se explicitó en los acuerdos de paz porque se daba por hecho que así seguiría siendo. Permitir que se produzca tal cambio de estatus en Irlanda del Norte sin el consentimiento de su ciudadanía es para él, a todas luces, contrario a la Constitución Británica y un paso atrás en el proceso de paz.

Lo mismo opina Daniel Holder, para quien la Convención de Sewel y el hecho de solicitar mociones de consentimiento a las devolved regions

(43) Sobre este punto: ATKINSON, Joe, "Parliamentary Intent and the Sewel Convention as a Legislatively Entrenched Political Convention». Ver: https://ukconstitutionallaw.org/2017/02/10/joe-atkinson-parliamentary-intent-and-the-sewel-convention-as-a-legislatively-entrenched-political-convention/ 
son parte de la Constitución Británica, toda una costumbre que se había establecido en los últimos años y que se debía respetar. Sin embargo, en su opinión, la Corte, sabedora de que ni Escocia ni Irlanda del Norte darían ese consentimiento, decidió que no era necesario para evitar así una crisis constitucional.

De hecho, como recuerda Wheare, si bien es cierto que la sentencia establece que las convenciones no son jurídicamente exigibles, lo cierto es que tradicionalmente han sido definidas como "reglas de comportamiento aceptadas como obligatorias(44)», algo que no se podría obviar. Es algo parecido a lo que opina el profesor Morison. En su opinión, los jueces decidieron no complicarse la vida, imponiendo una visión muy unitaria y centralizada de la soberanía, cuando a lo largo de los últimos años el Reino Unido ha dado pasos hacia su descentralización (45).

\section{Síntesis: Irlanda del Norte no puede frenar el Brexit}

El resumen de todo lo dicho por la sentencia es que Irlanda del Norte no tiene herramientas jurídico-constitucionales para frenar el Brexit, porque:

1) La materia relativa al artículo 50 TUE no es competencia de Irlanda del Norte, sino que es materia exceptuada en manos del Estado central, es decir, retenida por las instituciones centrales del Reino Unido.

2) La Asamblea de Irlanda del Norte no tiene una competencia legislativa paralela en relación al abandono de la UE por parte del Reino Unido, por lo que su consentimiento previo no resulta necesario. $Y$ ello porque aun siendo cierto que el art. 5 de la NI Act le otorga cierta capacidad legislativa, el art. 6 establece que ello no afecta a la capacidad del Parlamento del Reino Unido para legislar sobre Irlanda del Norte.

3) En ese mismo sentido, hay que recordar que si bien la Convención de Sewel establece que no se legislará desde Westminster sobre materias transferidas sin el consentimiento de las asambleas territoriales, lo cierto es que su valor según los tribunales es político, no siendo exigible jurídicamente. Ello, por supuesto, no excluye el gran coste político que podría tener para el Reino Unido "arrastrar»

(44) WHEARE, K., Modern Constitutions, Oxford University Press, Oxford, 1951, pág. 179.

(45) Manifestaciones realizadas en las entrevistas semiestructuradas celebrada en Belfast los día 29 y 30 de junio de 2017. 
a Irlanda del Norte o Escocia fuera de la UE (46), pero la convención no es jurídicamente vinculante.

4) Las referencias al consentimiento necesario por parte de la ciudadanía de Irlanda del Norte para cualquier cambio de su estatus constitucional no suponen un reconocimiento absoluto frente a cualquier cambio de estatus, sino que están limitadas a la pertenencia de dicho territorio al Reino Unido o a Irlanda, excluyéndose la pertenencia a la UE (47).

5) La evaluación de la igualdad de impacto de la legislación que recoge el artículo 75, no resulta aplicable al caso, por no ser un caso relativo a Irlanda del Norte específicamente ni estar el ministro del Brexit dentro de las autoridades públicas sujetas a la norma.

Por lo tanto, ni la Asamblea legislativa ni el ejecutivo de Irlanda del Norte poseen, a día de hoy, poderes formales que les permitan evitar la activación del proceso de abandono de la UE, y en consecuencia, el Gobierno del Reino Unido puede seguir con el Brexit con o sin el consentimiento de la Asamblea de Irlanda del Norte (48). Todo parece indicar, además, que nos podríamos encontrar ante el primer paso atrás en el proceso de descentralización del Reino Unido, ya que aun siendo incierto, se plantea que toda la normativa europea europea revierta a Westminster (sin descartar posibles transferencias futuras). (49)

(46) HESTERMAYER, Holger P., «How Brexit will happen...», op. cit., p. 17..

(47) Y de hecho, según parte de la doctrina, en la práctica los jueces reconocieron que el Brexit no suponía ningún cambio material en la posición constitucional de Irlanda del Norte. POLLEY, Owen; HOEY, David, "An agenda for Northern Ireland after Brexit. How to build a secure, peaceful and prosperous future", Sandel Ford Policy, London, 2017, pág. 5. Ver: http://globalbritain.co.uk/wp-content/ uploads/2017/03/Nls-future-after-Brexit-Final.pdf

(48) TONGUE, Jonathan, "The Impact and Consequences of Brexit for Northern Ireland", Constitutional Affairs, European Parliament, 2017, pág. 5.

(49) "The proposals in the EU Withdrawal Bill are at the other end of the spectrum from the Welsh suggestion. A category of 'retained EU law' is created and it is proposed that all such EU law revert to Westminster. Ministers have suggested that, at a later stage, some powers may again be devolved. In order to achieve this, the Withdrawal Bill amends the devolution statutes for Scotland, Wales and Northern Ireland. This is a development of great constitutional import as the first significant rolling back of devolution since the process started twenty years ago. Under the Sewel convention, such changes normally require the agreement of the devolved legislatures themselves. This was reaffirmed after the Scottish independence referendum as the unionist parties strove to assure the public that devolved powers would not be undermined. It does appear that Westminster will seek to gain such approval through legislative consent motions. This tests the Sewel convention to its limits. The Scottish and Welsh governments have indicated that they will not recommend consent, meaning that the motions would be voted down in the Scottish Parliament and the National Assembly for Wales». KEATING, Michael, "To devolve or not to devolve. The European Union (withdrawal) Bill and devolution». Ver: https://constitutionunit.com/2017/07/25/to-devolve-or-not-to-devolve-the-european-union-withdrawal-bill-and-devolution/ 


\section{Un apunte desde el Derecho Internacional Público: ¿Qué posibilidades tiene la República de Irlanda de condicionar el Brexit?}

Como se acaba de explicar, las posibilidades constitucionales con las que cuenta Irlanda del Norte para paralizar el Brexit son mínimas. Algo mayores parecen sin embargo las posibilidades que tiene la República de Irlanda de condicionar dicho proceso, y no sólo en condición de estadomiembro de la UE, sino como miembro signatario de un tratado internacional bilateral válidamente celebrado con el Reino Unido. Tratado que está inscrito en Naciones Unidas, y en el que ambos estados, "como amigables vecinos y socios en la UE", se comprometieron a respetar e implementar el acuerdo multipartidario de Viernes Santo (50).

Y el acuerdo multipartidario de Viernes Santo, huelga decirlo, tiene variadas referencias a la UE en los ejes uno, dos y tres; sobre todo en su eje 2 , referente a las áreas de cooperación norte-sur. Este eje presupone la pertenencia conjunta del Reino Unido e Irlanda a la UE como antecedente de los acuerdos, y propone que el Consejo Ministerial Norte-Sur, destinado a fomentar la colaboración, considere la dimensión comunitaria de las materias a tratar, incluida la aplicación de políticas y programas de la UE. Además, se habla también de que las opiniones del Consejo se tengan en cuenta y se representen adecuadamente en la UE (párrafo 17).

Se sugieren también una serie de materias de trabajo a tratar en el Consejo, citando expresamente "relevantes programas de la UE como SPPR, INTERREG, Leader II y sus sucesores»(Punto 8), y de hecho, uno de los principales instrumentos de cooperación norte-sur ha sido el SEUPB (Special European Union Programmes Body), que ha sido el encargado de implementar el programa europeo para la paz y reconciliación en Irlanda del Norte, con más de 2'3 billones (con B) de euros de financiación (51).

El Brexit requerirá, a buen seguro, eliminar o modificar aquellas referencias a la UE presentes en el acuerdo de Viernes Santo, ya que no siendo uno de sus signatarios miembro de la UE difícilmente se va a poder seguir implementando en los mismos términos de hoy en día. Y sin embargo, el Reino Unido está "obligado" a cumplir el acuerdo en sus actuales términos.

Se lo debe a la ciudadanía de Irlanda del Norte, ya que se comprometió ante ellos a apoyar y respetar el acuerdo. Pero es que además podría ser también algo exigible por Irlanda. Bajo el artículo 27 de la Convención de Viena, ningún estado puede invocar legislación doméstica -como

(50) Agreement between the Government of The United Kingdom of Great Britain and Northern Ireland and the Government of Ireland, art. 2.

(51) TONGUE, Jonathan, "The Impact and Consequences of Brexit for Northern Ireland", Constitutional Affairs, European Parliament, 2017, pág. 6. 
podría ser una ley del parlamento británico sobre el Brexit- como base para incumplir un tratado.

Sin embargo, el escenario más probable parece aquel en el que ambos gobiernos sigan colaborando y permitan la derogación o modificación de los puntos necesarios en el Acuerdo de Viernes Santo, sobre todo los del capítulo dos. No parece que Irlanda vaya a optar por confrontar y acudir a la Corte Internacional de Justicia. Y aunque así lo hiciere, además, la Corte poco podría hacer, ya que el Reino Unido excluye cualquier causa que lo enfrente con un país que pertenezca o haya pertenecido a la Commonwealth.

\section{El Brexit y sus implicaciones a futuro}

Tras el referéndum del Brexit y su sorprendente resultado, fueron realizados todo tipo de estudios y encuestas sociológicas para intentar explicar un voto que a mucha gente se le hacía inexplicable (52). ¿Quién y por qué habían votado leave?

\section{La sociedad norirlandesa ante el Brexit}

En general, los estudios coincidían en afirmar que la salida de la Unión Europea por parte del Reino Unido había sido apoyada en mayor medida por la clase trabajadora (fuertemente golpeada por la crisis económica) que por las clases medias (que votaron remain); que el leave tuvo más apoyos entre la gente adulta (tradicionalmente más conservadora) que entre la gente joven(53); y que obtuvo más apoyos entre los hombres que entre las mujeres.

Siendo esa la foto de lo que, en general, ocurrió en conjunto del Reino Unido, hay que decir que la explicación sociológica del voto a favor del Brexit en Irlanda del Norte tuvo características similares, si bien en este caso dicho voto fue minoritario, ya que frente a los 349.442 sufragios que votaron leave (44'2\%), 440.707 apoyaron la permanencia en la UE (55'8\%).

Según un estudio realizado por los profesores de la Queen's University de Belfast John Coakley y John Garry, en Irlanda del Norte el Brexit sólo ganó entre los hombres mayores de 45 años de clase trabajadora. Las clases medias, los jóvenes y las mujeres (tanto de clase media como trabajadora) apoyaron mayoritariamente el remain, con porcentajes que

(52) Para una breve explicación de los discursos de campaña: FRENCH, Duncan, «Brexit: A Constitutional ", op. cit., pp. 5-6.

(53) En el conjunto del Reino Unido, por edades, el Remain arrasó entre los jóvenes entre 18 y 24 años, alcanzando un 70\%, mientras que fue el Brexit el que ganó entre los mayores de 65 años, con un $60 \%$ de votos. FRENCH, Duncan, "Brexit: A Constitutional...», op. cit., pág. 3. 
van desde un escueto $52 \%$ en el caso de las mujeres de clase trabajadora mayores de 45 años a un abrumador $77 \%$ en el caso de las mujeres de clase media menores de 45 años (54).

\section{Figura 1}

Brexit preference by social grade, age and sex (\%)

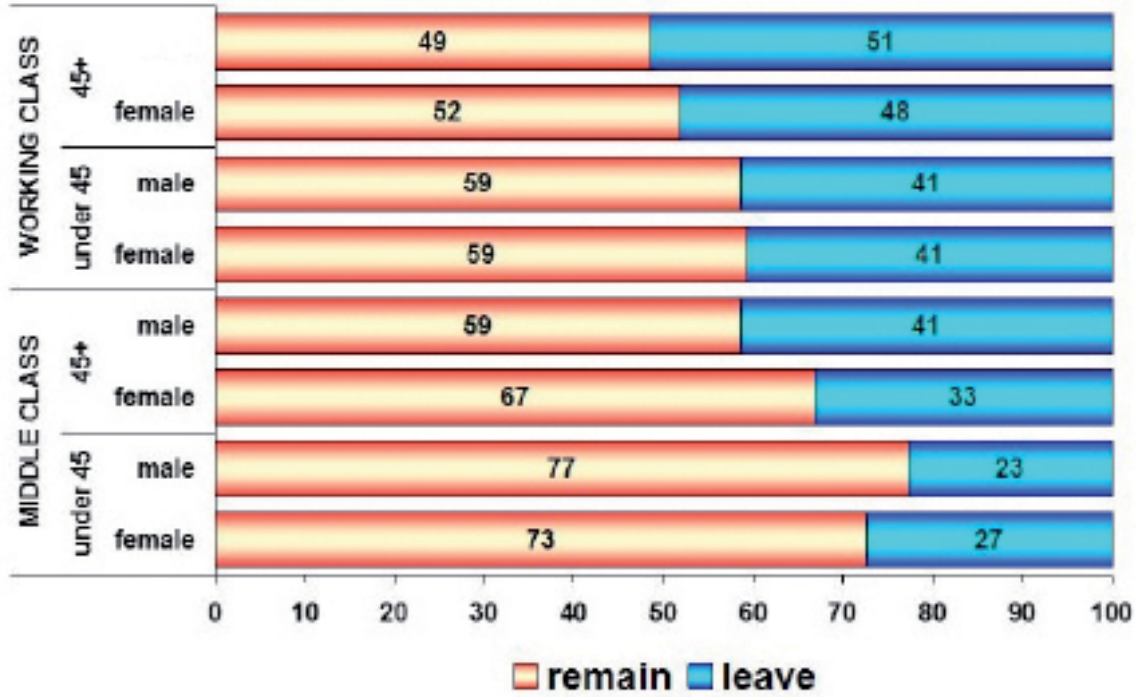

Por lo que respecta a las características sociológicas y políticas particulares de Irlanda del Norte, la tradicional división entre católicos y protestantes o republicanos y unionistas tuvo también su reflejo a la hora de explicar uno u otro voto, pero para ser exactos, no en sentidos completamente opuestos. Así, mientras que las áreas nacionalistas católicas votaron masivamente por el remain, en las zonas unionistas el voto estuvo más dividido, si bien se impuso el abandono de la UE.

El estudio mencionado muestra por ejemplo que mientras el $85 \%$ de los católicos apostó por permanecer en la UE, el apoyo al Brexit, aun siendo mayoritario, no obtuvo los mismos porcentajes entre la comunidad protestante, donde el apoyo al mismo fue de un $59 \%$.

A su vez, el $88 \%$ de quienes se consideran «irlandeses» habría apostado por el remain, mientras que sólo el $62 \%$ de quienes se consideran británicos habrían votado Brexit. Es remarcable, además, que quienes se identifican como "norirlandeses», según el estudio, apoyaron el remain claramente, con un $64 \%$.

(54) COAKLEY, John; GARRY, John, "Northern Ireland: The challenge of Public Opinion», Queen's University Belfast, 2016. Ver: http://qpol.qub.ac.uk/public-opinion-challenge-ni/ 
Finalmente, entre quienes se identificaron como "nacionalistas» la posición favorable a la UE se elevó hasta un $88 \%$, descendiendo a un $35 \%$ entre quienes se definieron como "unionistas" y ascendiendo de nuevo a un significativo $70 \%$ entre quienes no se definen ni por lo uno ni por lo otro (55), dato que parece importante de cara al futuro.

\section{Los partidos norirlandeses ante el Brexit}

Si llevamos estos datos al terreno político-partidario los datos son clarísimos: el apoyo a la permanencia en la UE es muy mayoritario entre los votantes de partidos nacionalistas (Sinn Feinn y SDLP) e incluso entre aquellos que no se definen en términos nacionales (APNI, Green o PBP). Por el contrario, entre los partidos unionistas, el apoyo al abandono de la UE parece no ser tan decidido en el UUP, aunque sí que es bastante consistente en el seno del mayoritario DUP (un 70\%).

Figura 2

Brexit preferemce by party (\%)

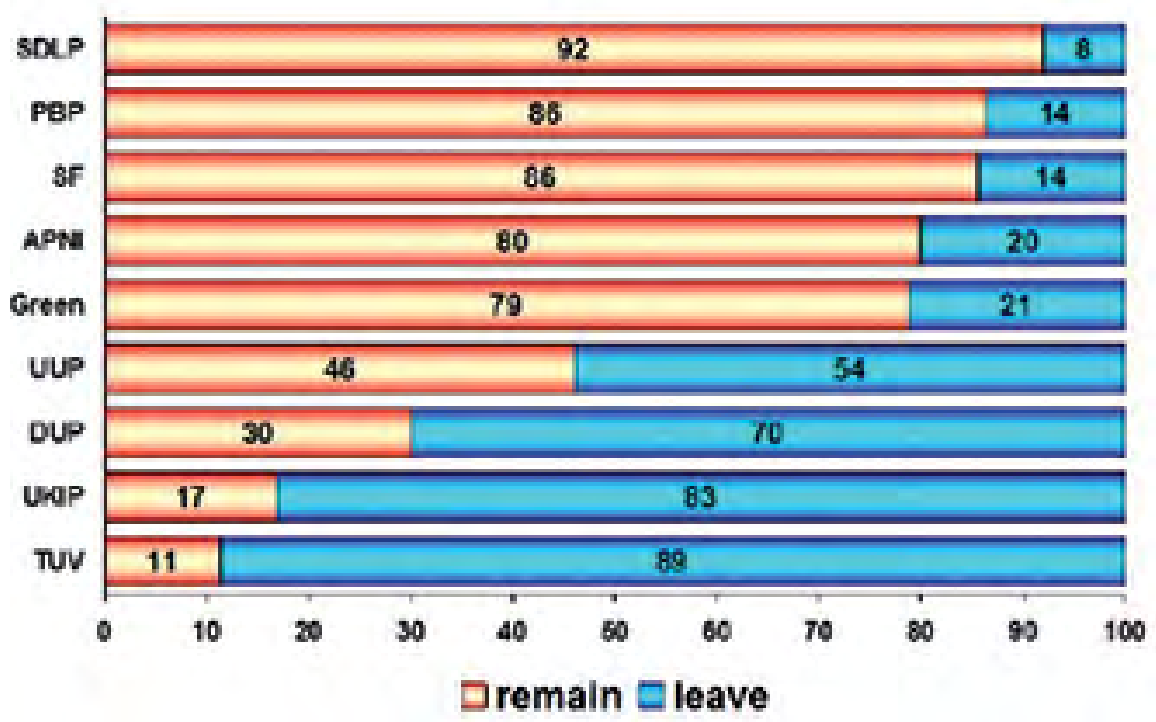

Si hacemos el ejercicio de llevar estos datos al terreno parlamentario los datos serían los siguientes:

(55) Idem. 
En las últimas elecciones regionales celebradas en Irlanda del Norte en marzo de 2017 los dos principales partidos republicanos, ambos opuestos al Brexit, obtuvieron 39 parlamentarios (27 el Sinn Féin y 12 el SDLP). A estos 39 parlamentarios se le unirían en el rechazo al Brexit los de varios partidos no alineados ni con el unionismo ni con el nacionalismo, como AllianceAPNI (8 parlamentarios), Green Party (2 parlamentarios) y el único independiente, haciendo un total de 50 votos claramente contrarios al Brexit.

Entre los partidos unionistas, sus dos principales exponentes, el DUP y el UUP, mantuvieron posiciones enfrentadas con respecto al Brexit durante la campaña del referéndum. Así, mientras el primero lo apoyó (y ganó las elecciones, aunque con un fuerte descenso y con tan sólo un parlamentario más que el Sinn Fein), el segundo hizo campaña por el remain, si bien a día de hoy afirma plenamente asumir el resultado global del referéndum.

Por último, estaría el parlamentario de PBP (People Before Profit) que sí que es abiertamente favorable al Brexit(56), aunque no en términos unionistas sino anticapitalistas, por no creer en esta UE.

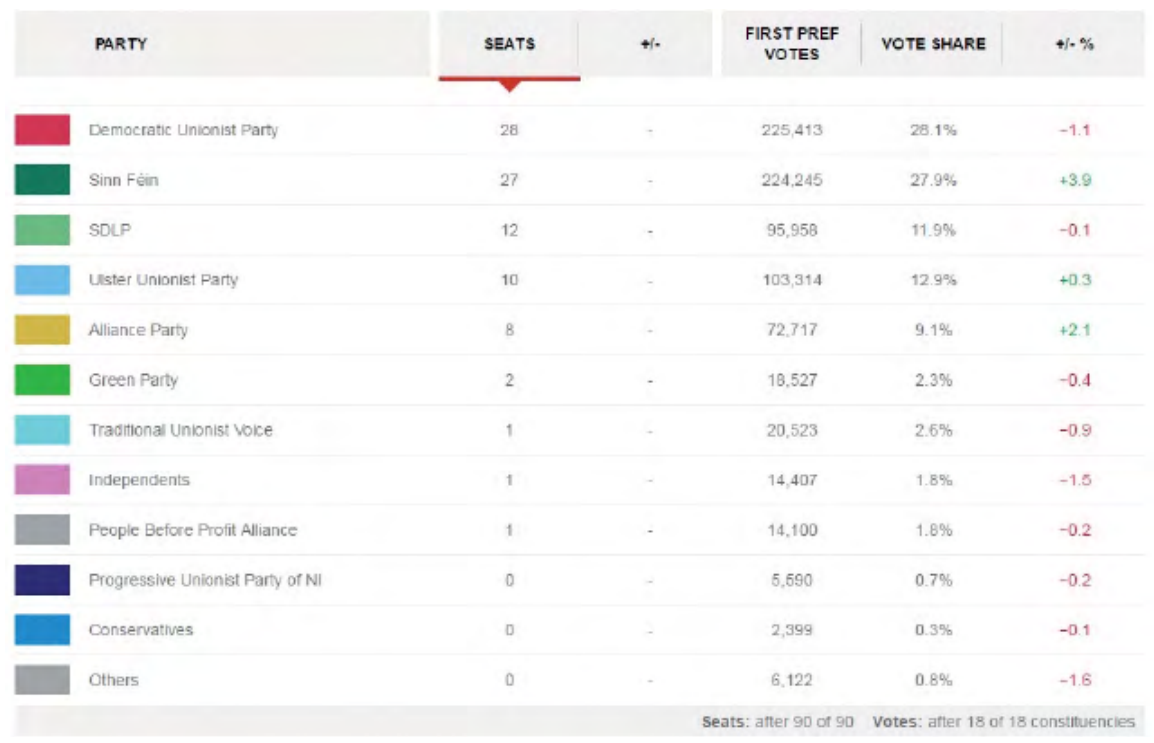

Fuente: British Broadcasting Corporation (BBC) (57)

(56) Para consultar un análisis sobre las elecciones legislativas en Irlanda del Norte: MURPHY, Mary C., "Northern Ireland: A casualty for Brexit?», Alliance Europa, 21/03/2017. Ver: http://allianceeuropa.ideasoneurope.eu/2017/03/21/northern-ireland-casualty-brexit/

(57) British Broadcasting Corporation (BBC), 2017. Ver: http://www.bbc.co.uk/news/election/ni2017/ results 
Los datos anteriores nos llevan a concluir que aun cuando se colocase al UUP entre las fuerzas favorables al Brexit (algo que no está del todo claro), a día de hoy en la Asamblea Legislativa de Irlanda del Norte existe una mayoría política clara de 50 contra 40 opuesta al mismo, que si bien no tiene capacidad de evitarlo jurídicamente, acaso sí tendría capacidad para condicionarlo políticamente.

De hecho, hay quien defiende que aunque Belfast no tendría posibilidad de paralizar lo que en el pasado se ha denominado como la "Great Repeal Bill» por ser esta excepted matter - ley que finalmente ha sido presentada ante el Parlamento como European Union (Withdrawal) Bill(58) - , no es menos cierto que competencia por competencia, podría intentar mantener la legislación derivada de la UE en aquellas áreas de su autoridad interna (59) (y no es poca, ya que se calcula que entre un 60 y un $80 \%$ de la legislación en las devolved regions tiene su origen último en la UE (60)). Por lo menos políticamente parece que tendría grandes posibilidades de hacerlo, ya que modificar algunas de dichas disposiciones exige en la Asamblea una mayoría intercomunitaria (cross-comunity consensus) que parece difícilmente conseguible (61).

De cara al futuro próximo, en cualquier caso, no parece que los partidos favorables al remain o incluso a la unión con Irlanda, vayan a limitarse a ello. De hecho, ya se han formulado propuestas políticas de calado.

El Sinn Féin, por ejemplo, ha propuesto que transitoriamente Irlanda del Norte permanezca dentro de la UE con un estatus especial, algo que cuenta con el apoyo - a la luz de los datos - de la mayoría ciudadana en Irlanda del Norte. Según este partido, todo ello se podría hacer desde el estatus constitucional actual, con el objetivo de mantener la unión económica y aduanera, el área común para desplazamientos y los programas de financiación europea en el marco del proceso de paz (62).

No conforme con ello, este partido republicano propone conseguir celebrar un referéndum sobre la unidad de Irlanda dentro de los próximos 5 años (63), algo para lo cual existe base legal. «El Brexit supone un desas-

(58) Ver: https://services.parliament.uk/bills/2017-19/europeanunionwithdrawal.html

(59) TONGUE, Jonathan, "The Impact and Consequences of Brexit for Northern Ireland", Constitutional Affairs, European Parliament, 2017, pág. 5.

(60) MOORE, Carolyn, "The impact of Devolution on EU-Level Representation: British Regional Offices in Brussels, Regional and Federal Studies, 17, 3, 2007, pp. 275-291.

(61) Good Friday Agreement, 3. Strand One, 5. (d).

(62) SINN FÉIN, "Sinn Féin Westminster election Manifiesto 2017». El documento se puede encontrar en la web del principal partido republicano irlandés: http://www.sinnfein.ie/files/2017/2017West minsterManifesto.pdf

(63) Idem. 
tre, pero también una oportunidad para abrir el debate y plantear el referéndum sobre la unidad de Irlanda", manifiesta el miembro del partido republicano, Robert McClenaghan (64). Y es por ello que ya se han puesto manos a la obra.

Además, no se encuentran sólos en esa reivindicación, ya que el otro partido republicano, el SDLP, ya se ha apresurado a exigir un referéndum sobre la unidad de Irlanda una vez concluida las negociaciones del Brexit(65).

Los no alineados de Alliance, de momento, apuestan por un «special deal» con la UE, pero está por ver qué decidirán una vez materializado el Brexit.

\section{Las posibilidades para un referéndum sobre la unidad de Irlanda}

Es incierto si los republicanos conseguirán en un futuro próximo la mayoría política suficiente que permita abrir esa vía. Vista la correlación de fuerzas actual y su evolución, no parece tarea fácil, pero tampoco imposible; al no haber impedimento legal alguno, se trataría "sólo" de generar una mayoría política e institucional suficiente que reclame dicho referéndum.

Si realizamos un breve análisis sobre la posibilidad de convocatoria de un referéndum vemos que existen factores tanto para fortalecer como para debilitar dicha opción.

Entre los que parecen fortalecer la posibilidad de convocatoria de un referéndum cabría destacar los siguientes:

1) El Brexit ha puesto sobre la mesa de la actualidad un debate que estaba absolutamente relegado en los últimos años: el debate sobre la unidad de Irlanda. Se trata de algo que manifiestan todos los expertos (66).

2) Por primera vez en la historia del Ulster las fuerzas unionistas no tienen mayoría en la Asamblea norirlandesa, estando empatadas con las fuerzas republicanas (frente a los 39 parlamentarios que suman Sinn Féin y SDLP, los unionistas de DUP, UUP y TUV suman otros 39).

(64) Entrevista semi-estructurada realizada en Belfast, el 29 de junio de 2017.

(65) Belfast Telegraph, 31/05/2017. Ver: http://www.belfasttelegraph.co.uk/news/general-election2017/sdlp-wants-referendum-on-irish-unity-after-brexit-talks-completed-35772997.html

(66) Manifestaciones realizadas en todas las entrevistas semi-estructuradas realizadas para este trabajo. 
3) Los partidos políticos contrarios al Brexit cuentan con una holgada mayoría en la Asamblea de Irlanda del Norte frente a aquellos que lo apoyan. Incluso si se cuenta al UUP como fuerza favorable al Brexit, los contrarios a tal medida son 50 frente a 40 .

4) La UE fue un elemento político de primer orden en el Acuerdo de Viernes Santo. Se ha recibido mucho apoyo para distintos programas del proceso de paz, incluidos fondos que se cuentan por billones de euros y que, como es lógico, se verían afectados por un futuro Brexit(67).

5) Todas las encuestas sociológicas realizadas durante los últimos años demuestran que la ciudadanía norirlandesa no quiere abandonar la UE y rechaza mayoritariamente el Brexit. Si cabe, con más fuerza desde el referéndum de 2016. Hay que tener en cuenta además que el Brexit todavía no ha sucedido, por lo que, según expertos, cabe pensar que en un futuro la voluntad de unión a Irlanda crecerá (68).

6) La unión con Irlanda es una de las posibles vías de garantizar el remain(69). De hecho, según algún estudio, tras el referéndum sobre el Brexit son el doble quienes creen que la probabilidad de una unión con Irlanda aumenta frente a quienes creen que disminuye (en cualquier caso, hay que matizar, para una mayoría todavía no influye decisivamente sobre dicha opción) (70).

7) Las últimas elecciones al Parlamento Británico celebradas el 7 de junio de 2017 han demostrado que el partido que más nuevos apoyos gana con respecto a los anteriores comicios es el Sinn Féin, que pasa de 4 a 7 escaños haciendo campaña pro-referéndum, y ello aun cuando había anunciado que no ocuparía sus asientos en Westminster.

8) En 2021 se cumplirá el primer centenario de la partición de la isla. Parece que los republicanos intentarán convertirlo en un acontecimiento(71) que permita dar impulso a sus aspiraciones y a la celebración del referéndum. La prensa ya se ha hecho eco de ello(72). Es su momentum.

(67) TANNAM, Etain, "Brexit and the Future of the United Kingdom», paper presented to Instituto Affari Internazionali Rome, Dublin, 12/07/2016, pág. 5.

(68) Es lo que manifestaron la totalidad de los entrevistados para el presente trabajo.

(69) Ver: http://www.telegraph.co.uk/news/2016/06/25/united-ireland-now-more-likely-than-ever/

(70) Ver: http://www.ark.ac.uk/nilt/2016/Political_Attitudes/UNIRLIKL.html

(71) Sobre el alcance y significado de acontecimiento: ZIZEK, Slavoj, Acontecimiento, Sexto Piso, Madrid, 2014.

(72) El Mundo, 14/04/2014, «El Brexit abre las puertas a la unificación de Irlanda». Ver: http://www.elmundo.es/internacional/2017/04/14/58ef8fa5468aeb75488b45bc.html 
La propia Unión Europea ya ha manifestado por boca del Consejo Europeo que de producirse tal referéndum y ganar la opción por la unidad de Irlanda, el conjunto de la isla pasaría a formar parte de la UE directamente (73), sin tener que ponerse Irlanda del Norte "a la cola" de los solicitantes de ingreso en la UE, tal y como sí se le viene exigiendo a Escocia en el hipotético caso de que optase por la independencia (74). EI hoy ex-primer ministro irlandés, Enda Kenny, ya mostró su satisfacción por ello (75).

Frente a dichos factores, existen otros que podrían alejar la opción de un referéndum:

1) Según un estudio elaborado por el ESRC (Economic and Social Research Council), en 2014 el estatus político de Irlanda del Norte contaba con un apoyo mayoritario por parte de la población; apoyo que sería cercano al $50 \%$, frente al $16 \%$ de apoyo al gobierno directo por parte de Londres y al $17 \%$ de apoyo a la reunificación irlandesa(76). Dicho apoyo no parece haber mermado inmediatamente tras el Brexit, ya que según el mismo estudio de 2016, el apoyo al actual estatus ascendería hasta el $54 \%$, mientras que el apoyo al gobierno directo por parte de Londres descendería al $12 \%$ y a una Irlanda unida subiría al 19\%(77) (este dato en cualquier caso se ha de matizar con otro: el Brexit todavía no es una realidad).

2) Aunque en la Asamblea las fuerzas unionistas estén en minoría con respecto a las republicanas, lo cierto es que en las últimas elecciones hubo más electores unionistas que republicanos. Un vistazo rápido a los resultados de aquellas elecciones permite

(73) Statement approved by European Council on 29 April 2017: «The European Council acknowledges that the Good Friday Agreement expressly provides for an agreed mechanism whereby a united Ireland may be brought about through peaceful and democratic means; and, in this regard, the European Council acknowledges that, in accordance with international law, the entire territory of such a united Ireland would thus be part of the European Union".

(74) Para consultar las líneas maestras de la negociación del Brexit por parte de la UE: EUROPEAN COUNCIL, «European Council guidelines (art. 50) for Brexit negotiations, 29/04/2017. Ver: http://www. consilium.europa.eu/en/press/press-releases/2017/04/29-euco-brexit-guidelines/

(75) Irish Times, 29/04/2017, "Enda Kenny welcomes EU's united Ireland agreement». Ver: http:// www.irishtimes.com/news/world/europe/enda-kenny-welcomes-eu-s-united-ireland-agreement1.3066687

(76) Ver: http://www.ark.ac.uk/nilt/2014/Political_Attitudes/NIRELND2.html

(77) Ver: http://www.ark.ac.uk/nilt/2016/Political_Attitudes/NIRELND2.html. Otros datos que no invitan al optimismo a los defensores del referéndum: según el mismo estudio, a día de hoy son menos quienes se sienten sólo irlandeses o más irlandeses que británicos (35\%), que aquellos que se sienten sólo británicos o más británicos que irlandeses (39\%). Ver: http://www.ark.ac.uk/nilt/2016/Political_Attitudes/IRBRIT.html Además, todavía hoy la gente no cree probable la posibilidad de una Irlanda unida (tan sólo para un $19 \%$ es muy probable o probable que eso pudiera suceder dentro de los próximos 20 años).Ver: http://www.ark.ac.uk/nilt/2016/Political_Attitudes/UNTDIREL.html. 
apreciar que mientras el número de votantes explícitamente republicanos (SF+SDLP) fue de 320.203 sufragios, el número de votos explícitamente unionistas (DUP+UUP+TUV+PUP) fue de 354.840. Es decir, casi 25.000 votos más, que podrían indicar que aun siendo por muy poco, todavía no hay una mayoría electoral favorable a la celebración de dicho referéndum y a la unión con Irlanda.

3) Dicha tendencia, lejos de verse debilitada, se ha visto ligeramente fortalecida tras las últimas elecciones al Parlamento de Westminster, donde el DUP se impuso con holgura a los republicanos del Sinn Féin (78), reflejando nuevamente una mayoría unionista en Irlanda del Norte.

4) El factor del segundo referéndum de independencia en Escocia, que podría actuar como catalizador de otro similar en Irlanda, parece alejarse tras las últimas elecciones al Parlamento Británico. La presidenta y portavoz del Scottish National Party (SNP), principal partido nacionalista escocés, ha insinuado tras las elecciones que la defensa del segundo referéndum ha podido ser uno de los principales factores que explique su importante pérdida de apoyos, por lo que no parece que en el corto plazo vayan a intensificar su labor pro-referéndum (79) (En cualquier caso, también han aclarado que no desisten de su apuesta, por lo que este factor no se puede desechar de cara al futuro).

5) El Gobierno Británico, por boca de su Primera Ministra Theresa May, ya ha dejado claro que no es el momento de organizar un referéndum por la unidad de Irlanda(80), de forma que no se cuenta con su apoyo o colaboración para organizarlo. En cualquier caso, la posibilidad del referéndum está en la ley, por lo que incluso los tribunales podrían ordenar organizarlo (es una posibilidad que sugirió en entrevista el experto Daniel Holder).

6) Y por último, el propio Sinn Féin, principal fuerza republicana, asume como paso táctico la posibilidad de que se logre un estatus especial para Irlanda del Norte dentro de la Unión Europea. Siendo esto así, la unión a Irlanda no se proyectaría ya como la única op-

(78) El resultado, en escaños, fue el siguiente: DUP 10, SF 7, Independientes 1, Alliance 0, SDLP 0 y UUP 0. British Broadcasting Corporation (BBC), 08/06/2017. Ver: http://www.bbc.co.uk/news/live/uknorthern-ireland-40161885

(79) The Guardian, 09/06/2017, «Nicola Sturgeon hints independence off agenda after SNP loses seats. Scotland's first minister says she will seek progressive alliance with Labour and admits second referendum was factor in losing 21 seats". Ver: https://www.theguardian.com/politics/2017/ jun/09/nicola-sturgeon-hints-independence-off-agenda-catastrophic-losses

(80) The Independent, 14/03/2017. Ver: http://www.independent.co.uk/news/uk/politics/northern-ireland-referendum-leave-uk-sinn-fein-theresa-may-response-at-this-stage-a7629281.html 
ción para permanecer en Europa, lo cual podría disuadir a distintas fuerzas no alineadas de apostar por un referéndum y la unidad de la isla como vía para mantenerse en la UE.

\section{Conclusiones}

Por el momento, parece demasiado aventurado predecir con certeza qué es lo que va ocurrir en Irlanda del Norte durante los próximos años, y en consecuencia, optar por una de las tres vías que se comentaban al principio de este texto resulta, todavía, harto difícil.

Está fuera de toda duda que el Brexit va a ser un acontecimiento político de primer orden que el día en que se produzca tendrá un impacto importantísimo tanto en Europa como en el Reino Unido e Irlanda del Norte. Sin embargo, a la hora de vaticinar alternativas de futuro tal vez haya que esperar a ver cómo se desarrolla el proceso de desconexión con la UE, qué tipo de Brexit se impone (si uno duro o uno más soft) y cuáles son sus consecuencias. El hecho de que ni siquiera sus principales promotores parezcan tener una idea clara sobre ello no hace sino complicar las cosas (81).

Dicho esto, según algunos analistas, el estatus jurídico-político de Irlanda del Norte ha contado hasta ahora con un relevante apoyo por parte de la ciudadanía porque una mayoría (incluso algunos nacionalistas) ha podido ver en el Reino Unido cierta estabilidad económica y estándares de bienestar que no ha querido poner en riesgo. Sin embargo, dicen, si se incrementa la incertidumbre sobre el futuro o, sencillamente, tras el Brexit esos estándares van a peor, la cosa podría cambiar por completo (82).

No es descartable que así suceda, ya que, en opinión de buena parte de los autores estudiados y entrevistados, el Brexit va a ser un "auténtico desastre" para el norte de la isla. Su preocupación es comprensible. Tal y como pone en evidencia un informe de la Cámara de los Lores, Irlanda del Norte es el territorio del Reino Unido más dependiente de las ayudas europeas; su pérdida "podría ser devastadora». Por ello, incluso desde dicha Cámara se ha solicitado al Gobierno Británico que durante las negociaciones del Brexit procure que por lo menos parte de dichas ayudas se mantengan, especialmente para proyectos transfronterizos (83).

(81) FRENCH, Duncan, "Brexit: A Constitutional...», op. cit., pp. 9-13.

(82) TANNAM, Etain, "Brexit and the Future...», op. cit., pág. 13.

(83) EUROPEAN UNION COMMITTEE, Brexit: UK-Irish relations, House of Lords, London, 12/12/2016, pp. 47-48. 
Para entender la gravedad de la situación basta con darse cuenta de que Irlanda del Norte ha sido un clarísimo beneficiario neto de las ayudas europeas, y no sólo aquellas referidas al proceso de paz, que se cuentan por billones (con b) de euros. El importante sector agro-ganadero y pesquero, por ejemplo, ha recibido fuertes ayudas durante los últimos años. ¿Qué hará el Reino Unido? ¿Sustituirá la PAC con una versión propia? (84)

En el terreno económico, que es probablemente la clave de las negociaciones del Brexit (junto con el control o no de fronteras), las alternativas más probables parecen ser tres (85): 1) Seguir el "modelo Noruego»; es decir, que el Reino Unido salga de la UE pero permaneciendo en el Espacio Económico Europeo(86). 2) Seguir el «modelo Suizo», celebrando un tratado bilateral de libre comercio. Y 3) Seguir el modelo OMC, que vendría a ser el más separado de la UE.

En cualquiera de los 3 escenarios una cosa es clara. Irlanda del Norte va a ser el único territorio de fuera de la UE en el que todos sus ciudadanos tienen reconocido el derecho a ostentar ciudadanía europea, por lo que no parece descartable la hipótesis de que se le reconozca al respecto un estatus especial. En este tipo de casos la UE suele apostar por el pragmatismo, por solucionar problemas en lugar de crearlos, así que no es descartable que esté abierta a realizar un acuerdo a medida (87).

Además, la posición de la República de Irlanda parece favorable. Su Gobierno ya ha dejado claro que hará todo cuanto esté a su alcance para que el Brexit no suponga una merma en el proceso de paz ni en los derechos fundamentales de los ciudadanos de Irlanda del Norte, para lo cual se ha planteado tácticamente cuatro principales objetivos: 1) Evitar el establecimiento de una frontera dura que ahonde en la división; 2) Garantizar que se respeta el contenido del Acuerdo de Viernes Santo; 3) Garantizar la continuación de los compromisos de la UE con Irlanda del Norte; y 4) Proteger el "estatus único» de los ciudadanos irlandeses de Irlanda del Norte (88).

Por último, como ya se ha mencionado, la puesta en marcha del proceso para abandonar la UE por parte del Reino Unido ha tenido una con-

(84) CARMICHEL, Paul, "Reflections from Northern Ireland on the result of the UK Referendum on EU Membership", en: GUDERJAN, Marius, The Future of the UK. Between Internal and External Divisions, Kosmos-Humboldt-Universität Zu Berlin, 2016, pág. 95.

(85) KPMG, «Brexit, A Northern Ireland Perspective», Ireland, June 2016, pág. 4.

(86) Sobre esta opción: DOHERTY, Brian (et al.), «Northern Ireland and Brexit:The European Economic Area Option», European Policy Centre, 07/04/2017.

(87) EUROPEAN UNION COMMITTEE, Brexit: UK-Irish relations, op. cit., pág. 58.

(88) IRISH GOVERNMENT, Ireland and the negotiations on the UK's withdrawal from the European Union. The Governments approach, Irish Government Publication, Dublin, May 2017, pág. 19-22. 
secuencia política clarísima. Ha traído al centro del debate político un tema que estaba absolutamente relegado: el fin de la partición y la consecuente reunificación de Irlanda; norte y sur.

Por ahora, no parece que exista una mayoría socio-política clara que exija la celebración del referéndum (tal y como establece el Acuerdo de Paz de Viernes Santo y el art. 1 de la NI Act); pero en un futuro próximo, no es en absoluto descartable. Los expertos consultados, desde luego, así lo consideran (Kieran McEvoy, Daniel Holder o Colin Harvey).

Por ello, para los republicanos, aun considerando que el Brexit es un desastre absolutamente rechazable, supone también una oportunidad, ya que podría ser una especie de "tormenta perfecta" que alterase las mayorías políticas al norte de la isla. En 2021 se cumplen además 100 años de la partición de Irlanda y no parece que vayan a dejar pasar esta oportunidad de darle fin. Tienen a su favor dos cosas. Por una parte, la evolución sociológica: mientras en 1921 (al tiempo de la partición) la población protestante/unionista al norte de la isla era un $70 \%$ (89), a día de hoy viene a suponer un $40-45 \%$ del electorado. Por otra, el Gobierno de Irlanda ha arrancado a la UE el compromiso de que si el referéndum se celebra y gana la apuesta por la unidad, el ingreso en la UE será automático, lo cual parece a todas luces beneficioso para los republicanos (90). Veremos qué pasa.

\section{Bibliografía}

ALONSO, Rogelio, Una historia de guerra y la búsqueda de la paz, Editorial Complutense, Madrid, 2001.

BOGDANOR, The New British Constitution, OUP, Oxford, 2009.

BOWERS, Paul, «The Sewel Convention», House of Commons Library, 25 November 2005.

BRUCE, Alan, «The fractured island: Divided sovereignty, identity and politics in Ireland", Journal of Conflictology, 4 (2), 2013.

BUSTOS GISBERT, Rafael, «La desnudez de la Constitución británica. Crónica marciana de la Sentencia de la Corte de Justicia del Reino Unido de

(89) BRUCE, Alan, «The fractured island..., op. cit., pág. 16.

(90) IRISH GOVERNMENT, Ireland and the negotiations on the UK's withdrawal from the European Union. The Governments approach, Irish Government Publication, Dublin, May 2017, pág. 19-22. No falta, además, quien asume claramente que el Gobierno irlandés está trabajando por los intereses de Irlanda del Norte más que el Reino Unido. WALKER, Brian, «The Irish Government is pursuing Northern Ireland's interests more actively than the UK government". Ver: https://constitution-unit. com/2017/05/23/the-irish-government-is-pursuing-northern-irelands-interests-more-actively-thanthe-uk-government/ 
24 de enero de 2017», Revista Española de Derecho Europeo, 62, abriljunio de 2017.

CAIRA, Rocco, "El Acuerdo de Viernes Santo y los Derechos Humanos", Cuadernos de Deusto de Derechos Humanos, 45, Universidad de Deusto, Bilbao, 2007.

CARMICHEL, Paul, "Reflections from Northern Ireland on the result of the UK Referendum on EU Membership», en: GUDERJAN, Marius, The Future of the UK. Between Internal and External Divisions, Kosmos-Humboldt Universität Zu Berlin, 2016.

CENTRE FOR CROSS BORDER STUDIES, «Briefing Paper1: The UK Referendum on Membership of the EU:What does it mean for us?", EU Referendum Briefing Papers, 2016.

COAKLEY, John; GARRY, John, "Northern Ireland: The challenge of Public Opinion", Queen's University Belfast, 2016.

CRUSET, María Eugenia, "El Acuerdo de Viernes Santo y su realidad hoy", Revista Contemporánea, 1, 1, 2011.

DICEY, Albert Venn, Introduction to the Study of the Law of the Constitution, Liberty Classics, Indianapolis (USA), 1982. Ver: http://files.libertyfund. org/files/1714/0125_Bk.pdf

DOHERTY, Brian (et al.), "Northern Ireland and Brexit: The European Economic Area Option», European Policy Centre, 07/04/2017.

DOUGLAS-SCOTT, Sionaid, "A UK exit from the EU: The end of the United Kingdom or a new constitutional dawn?», Legal Research Paper Series, Oxford University, March 2015.

"Brexit, the referéndum and the UK Parliament: Some questions about sovereignty". Ver: https://ukconstitutionallaw.org/2016/06/28/sionaidhdouglas-scott-brexit-the-referendum-and-the-uk-parliament-somequestions-about-sovereignty/.

EECKHOUT, Piet, "The UK decision to withdraw the EU: parliament or government?». Ver: https://constitution-unit.com/2016/10/27/the-uk-decision-to-withdraw-from-the-eu-parliament-or-government/

EUROPEAN COUNCIL, «European Council guidelines (art. 50) for Brexit negotiations, 29/04/2017.

EUROPEAN UNION COMMITTEE, Brexit: UK-Irish relations, House of Lords, London, 12/12/2016.

FITZDUFF, Mari, Más allá de la violencia. Procesos de resolución de conflicto en Irlanda del Norte, Bakeaz, Bilbao, 1998.

FRENCH, Duncan, «Brexit: A Constitutional, Diplomatic and Democratic Crisis. A View from the Trenches", PER/PELJ 2016 (19), Potchefstroom (South Africa), 29 september 2016.

GODDEN, Andrew; McCORMICK, Conor, "A new relationship? Brexit, Republic of Ireland and Northern Ireland", Constitutional Conversations, 3/6, Royal Irish Academy and Queen's University Belfast, 2016. 
HESTERMAYER, Holger P., «How Brexit will happen: A Brief Primer on EU Law and Constitutional Law Questions Raised by Brexit»; Journal of International Arbitration, King's College, London, 2016.

IRISH GOVERNMENT, Ireland and the negotiations on the UK's withdrawal from the European Union. The Governments approach, Irish Government Publication, Dublin, May 2017.

KEATING, Michael, «To devolve or not to devolve. The European Union (withdrawal) Bill and devolution". Ver: https://constitution-unit. com/2017/07/25/to-devolve-or-not-to-devolve-the-european-union-withdrawal-bill-and-devolution/

KPMG, "Brexit, A Northern Ireland Perspective», Ireland, June 2016.

MOORE, Carolyn, «The impact of Devolution on EU-Level Representation: British Regional Offices in Brussels, Regional and Federal Studies, 17, 3, 2007.

MURPHY, Mary C., "Northern Ireland: A casualty for Brexit?», Alliance Europa, 21/03/2017.

NORTH-SOUTH INTERPARLIAMENTARY ASSOCIATION, "Paper 1: Impact of Brexit on cross-border activity", Northern Ireland Assembly and Houses of the Oireachtas, 18/11/2016.

POLLEY, Owen; HOEY, David, «An agenda for Northern Ireland after Brexit. How to build a secure, peaceful and prosperous future», Sandel Ford Policy, London, 2017.

REID, Paul, "Time to give Sewel Convention some (political) bite?». Ver: https://ukconstitutionallaw.org/2017/01/26/paul-reid-time-to-give-thesewel-convention-some-political-bite/

SCOTTISH GOVERNMENT, «Memorandum of Understanding and Supplementary Agreements between the United Kingdom Government, the Scottish Ministers, the Welsh Ministers and Northern Ireland Executive Committee». Ver: http://www.gov.scot/Resource/0043/00436627.pdf

SINN FÉIN, "Sinn Féin Westminster election Manifiesto 2017».

TANNAM, Etain, "Brexit and the Future of the United Kingdom», paper presented to Instituto Affari Internazionali Rome, Dublin, 12/07/2016.

TONGUE, Jonathan, «The Impact and Consequences of Brexit for Northern Ireland", Constitutional Affairs, European Parliament, 2017.

WALKER, Brian, "The Irish Government is pursuing Northern Ireland's interests more actively than the UK government». Ver: https://constitution-unit.com/2017/05/23/the-irish-government-is-pursuing-northernirelands-interests-more-actively-than-the-uk-government/

WHEARE, K., Modern Constitutions, Oxford University Press, Oxford, 1951.

ZIZEK, Slavoj, Acontecimiento, Sexto Piso, Madrid, 2014. 


\section{Normativa}

Government of Ireland Act (1920).

Irish Constitution (1937).

European Communities Act (1972)

Agreement between the Government of The United Kingdom of Great Britain and Northern Ireland and the Government of Ireland (1998).

The Northern Ireland Peace Agreement. The Multi-Party Agreement (1998). Northern Ireland Act (1998).

European Union Referendum Act (2015).

European Union (Withdrawal) Bill (2017-2019)

\section{Jurisprudencia}

Sentencia de la Corte Superior de Belfast de 29 de octubre de 2016: McCord's (Raymond) Application [2016] NIOB 85:

https://www.courtsni.gov.uk/en-GB/Judicial\%20Decisions/PublishedByYear/ Documents/2016/\%5B2016\%5D\%20NIQB\%2085/___MAG10076Final.htm.

Sentencia de la Corte Suprema del Reino Unido de 24 de enero de 2017: JUDGMENT R (on the application of Miller and another) (Respondents) $\checkmark$ Secretary of State for Exiting the European Union:

https://www.supremecourt.uk/cases/docs/uksc-2016-0196-judgment.pdf

\section{Entrevistas semi estructuradas}

Dr. Kieran McEvoy. Profesor de Derecho y JusticiaTranscional en la Queen's University Belfast e investigador en el Institute of Conflict Transformation and Social Justice.

http://pure.qub.ac.uk/portal/en/persons/kieran-mcevoy(c9ea4e5d-156a4dc6-8d5c-5371712cbf9b).html

Dr. Colin Harvey. Profesor de Derechos Humanos en la Facultad de Derecho de la Queen's University Belfast y miembro del The Senator George J Mitchell Institute for Global Peace, Security and Justice. http://pure.qub.ac.uk/portal/en/persons/colin-harvey(b78326e0-78c4437b-9d23-9cd6217db870).html

Dr. John Morison. Profesor de Jurisprudencia en la Queen's University Belfast y miembro del The Senator George J Mitchell Institute for Global Peace, Security and Justice.

http://pure.qub.ac.uk/portal/en/persons/john-morison(a7784075-7a2f47a4-bdd5-f6fb934d0d8d).html 
Robert McClenaghan. Miembro del Sinn Féin y trabajador comunitario. Daniel Holder. Director Adjunto de la ONG especializada en Derechos Humanos Committee on the Administration of Justice. http://www.caj.org.uk/staff

Trabajo recibido el 18 de julio de 2017

Aceptado por el Consejo de Redacción el 20 de octubre de 2017 
LABURPENA: Idazlan honen helburua Brexit-ak Ipar Irlandan uzten duen eskenatokiaren azterketa egitea da, aintzat hartuta Brexit-a Ipar Irlandako herritarren gehiengoaren aurka gauzatuko dela. Horretarako, lehenik, lurralde honek egun duen estatus juridiko-politikoaren azalpena egingo da. Bigarrenik, Brexit-aren ondorio juridiko-konstituzionalen azalpena egingo da, bereziki erreparatuz Ipar Irlandak hura frenatu edota baldintzatzeko dituen tresnei. Hirugarrenik, azken hauteskundeen ondotik geratu den eskenatoki politikoaren azalpena egingo da; eta azkenik, ondorio moduan, etorkizunari begirako aukerak aztertuko dira. ¿Brexit-ak Irlandaren batasunera hurbiltzen gaitu? ¿Erreferendumik egongo da?

GAKO HITZAK: Brexit. Ipar Irlanda. Erreferenduma. Europar Batasuna.

RESUMEN: El presente trabajo analiza el incierto escenario que deja en Irlanda del Norte el Brexit, que cuenta con el rechazo de la mayoría ciudadana norirlandesa. Para ello, se explicará primeramente cuál es el estatus jurídico-político que tiene Irlanda del Norte a día de hoy. En segundo lugar, se explicarán las implicaciones jurídico-constitucionales del Brexit así como las herramientas legales que tiene Irlanda del Norte para frenarlo o condicionarlo. En tercer lugar, se analizará el escenario político que queda en la isla tras las últimas elecciones; y en cuarto y último lugar, a modo de conclusión, se analizarán las opciones de futuro. ¿Nos acerca el Brexit a la unidad de Irlanda? ¿Habrá referéndum?

PALABRAS CLAVE: Brexit. Irlanda del Norte. Referéndum. Unión Europea.

ABSTRACT: The aim of this paper is to analyze the uncertain scenario that Brexit, which is rejected by a majority of the Northern-Irish society, leaves in Northern Ireland. With this purpose, we first explain the legal-political status of Northern Ireland nowadays. Secondly, we explain the legal and constitutional implications of the Brexit as well as the legal tools that Northern Ireland has to curb or condition it. Thirdly, we analyze the political scenario that remains on this devolved region after the last elections; and finally, we analyze future options. Are we approaching the unity of Ireland? Will there be a referendum?

KEYWORDS: Brexit. Northern Ireland. Referendum. European Union. 